\title{
An Insight into the Crystallographic Aspects of Androstanes
}

\author{
SONIA SHARMA and RAJNI KANT \\ X-ray Crystallography Laboratory, Post-Graduate Department of Physics, \\ University of Jammu, Jammu Tawi -180 006, India \\ rkant.ju@gmail.com
}

Received 30 June 2015 / Accepted 12 July 2015

\begin{abstract}
In this paper, an attempt has been made to carry out a crystallographic comparison of some geometrical and structural features for a series of androstane derivatives of steroids. Selected bond distances and bond angles of interest in a series of forty- five androstane derivatives have been discussed in detail, besides conformations of individual ring systems, their graphical presentation and their frequency of occurrence. Intra- and intermolecular interactions of the type $\mathrm{X}-\mathrm{H}$...A $[\mathrm{X}=\mathrm{C}, \mathrm{O}$; $\mathrm{A}=\mathrm{O}, \mathrm{Cl}, \mathrm{Br}, \mathrm{F}]$ in androstane derivatives have been computed and discussed primarily on the basis of distance-angle scatter for better understanding of molecular packing in androstane derivatives.
\end{abstract}

Keywords: Steroids, Intermolecular interactions, Hydrogen bonding, Conformations

\section{Introduction}

Androstane molecule comprises of a four ring structure of which three are six- membered cyclohexane rings and one is five-membered cyclopentane ring with angular methyl groups located at $\mathrm{C} 10$ and $\mathrm{C} 13$ positions, respectively (Figure 1) ${ }^{1}$. The most important class of androstane-based steroids androgens which are primarily responsible for the production of masculinisation characterstics, i.e., they maintain the normal structure and function of the prostate gland and seminal vesicle; growth and pigmentation of the scrotum ${ }^{2}$. In addition, they influence the development of secondary male characterstics: hair distribution and deepening of voice. Administration of androgens results in retention of nitrogen, phosphorous and potassium together with a lowering of the respiratory quotient, which implies the use of body fat for protein biosynthesis ${ }^{3}$.

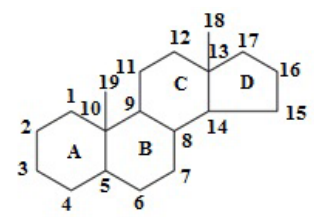

Figure 1. Basic androstane molecule (C19) with atomic numbering scheme 
The major naturally occurring compounds that possess androgenic activity are testosterone, $5 \alpha$-Dihydrotestosterone $(5 \alpha-\mathrm{DHT})$ and 4-androstenedione. Structurally, testosterones are characterised by: a double bond at $\mathrm{C} 4$ and an oxo group at $\mathrm{C} 3$ position (b) a hydroxyl group at $\mathrm{C} 17$ (c) The absence of a double bond at $\mathrm{C} 4$ and presence of hydrogen atom at cis (C5) position, thus giving rise to $5 \alpha$-DHT. Therefore, it is possible to correlate the structural features of androgens and their physiological actions as follows: for a $\mathrm{C}_{19}$ steroid to be androgen, a 17-oxygen function should be present with, either the 4-en-3-oxo configuration (as in testosterone) or a 3-oxo group and a saturated A- ring (as in 5 $\alpha$-DHT). If the 17-oxygen function is absent, as in 4, 16-androstadien-3-one, androgenic activity is completely lost ${ }^{4}$. If oxidation of the $17 \beta$-hydroxyl group occurs to give a 17 -oxosteroid, as in the case of testosterone being converted to 4 -androstenedione or -DHT to $5 \alpha$-androstane3, 17-dione, then androgenecity be reduced or lost completely. The 3-oxo-group is also necessary for androgenecity, even though the $17 \beta$-hydroxyl is intact in this case ${ }^{5}$.

The present work provides a comprehensive information about biological activity, structural features and packing interactions/hydrogen bonding in androstane derivatives. Here, we have identified a series of forty- five derivatives of androstane from the literature (CCDC). The chemical structure of each molecule (1-45) is shown in Figure 2. The reference code, chemical name, chemical formula, molecular weight and published reference $^{6-41}$ of each molecule is presented in Table 1.

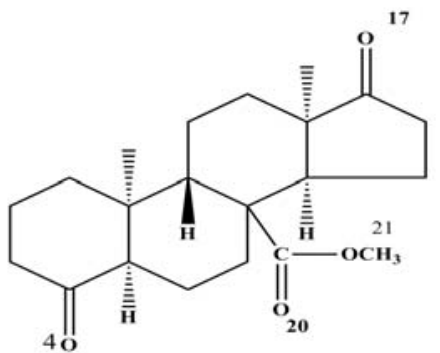

(1)

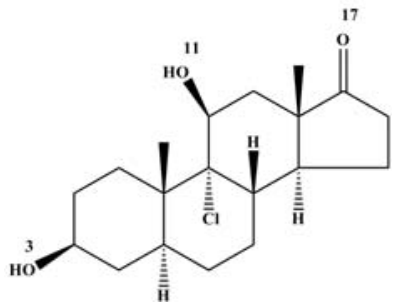

(3)

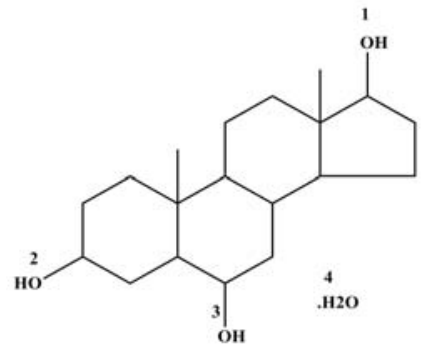

(5)

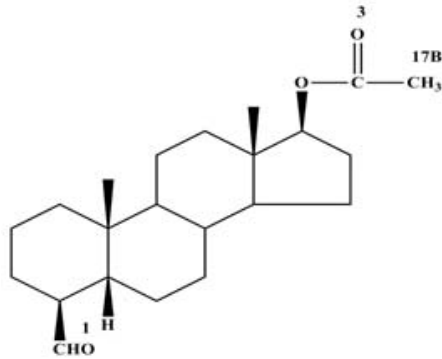

(2)<smiles>COC(=O)C12C(=O)CCCC1CC(=O)C1C2CCC2(C)C(=O)CCC12O</smiles>

(4)

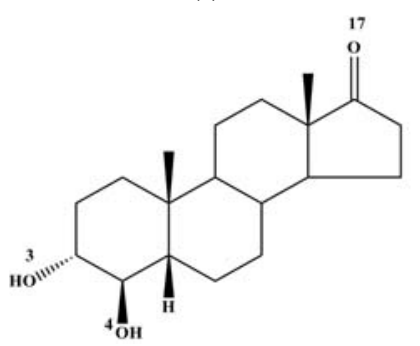

(6) 


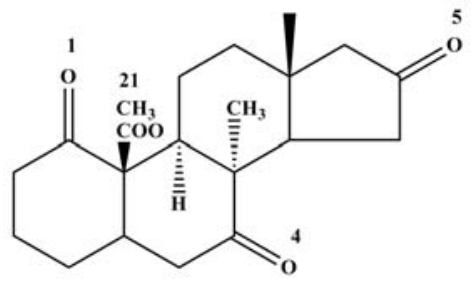

(7)

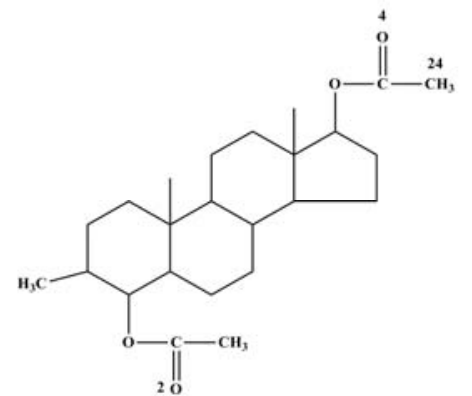

(9)

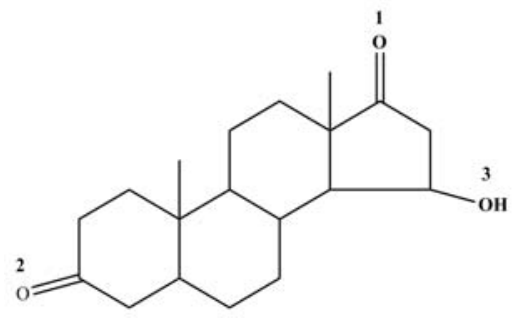

(11)

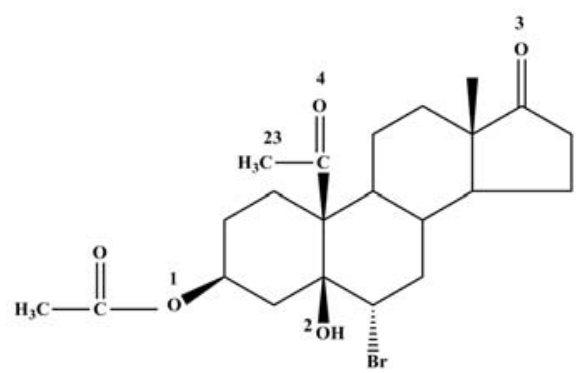

(13)

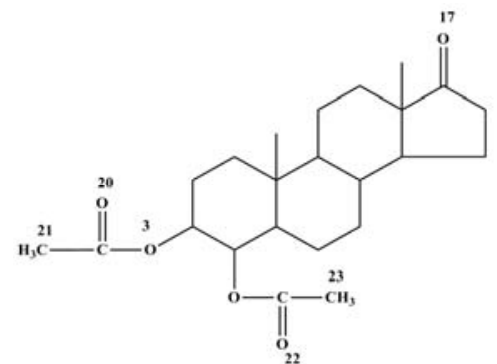

(15)

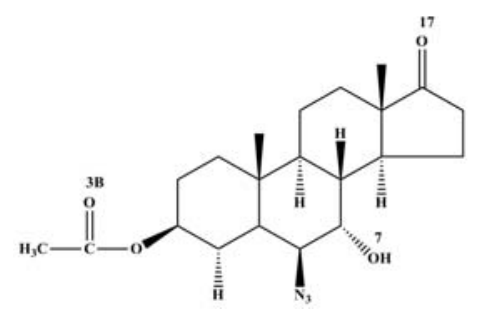

(8)

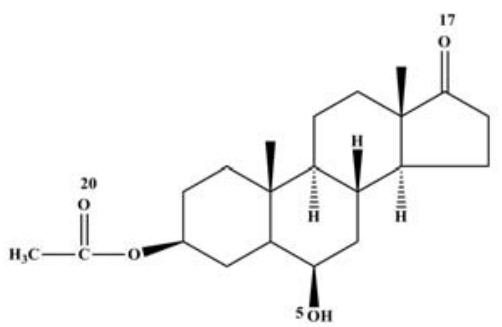

(10)

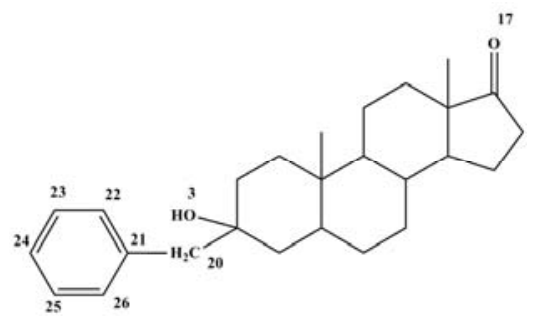

(12)

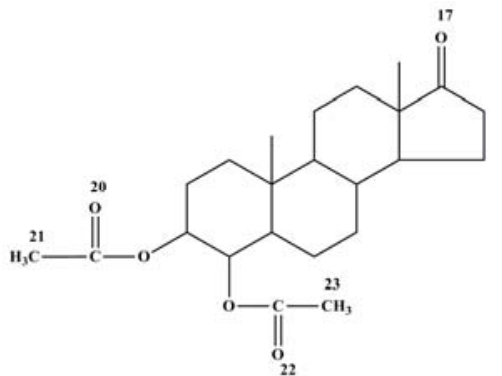

(14)

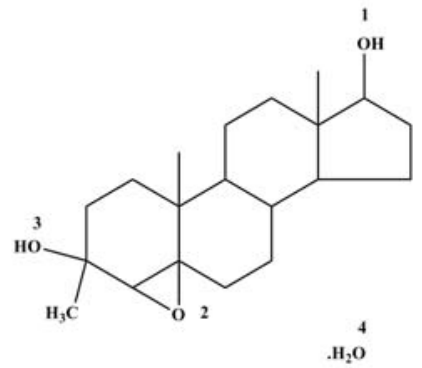

(16) 


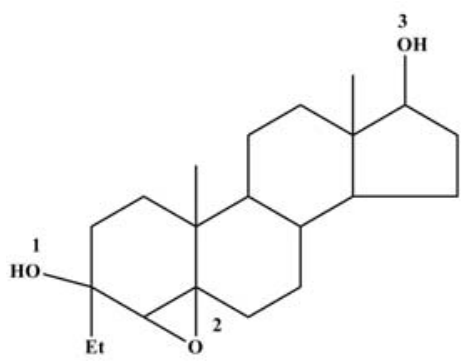

(17)
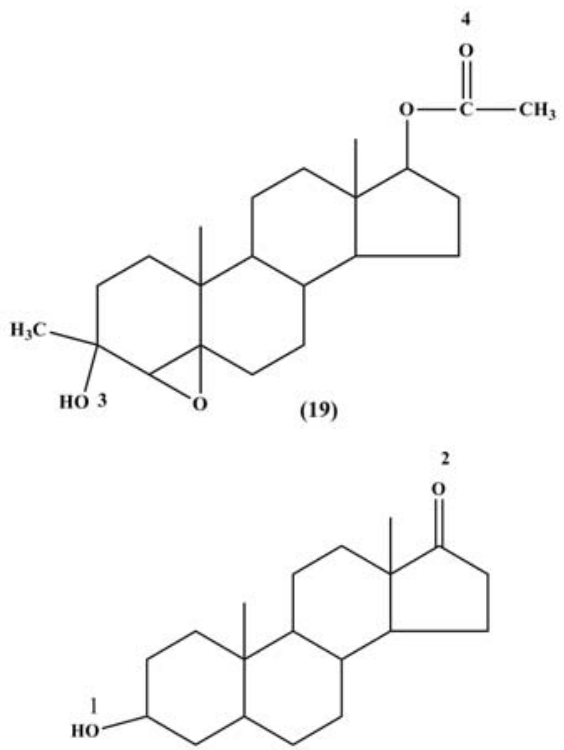

(21)

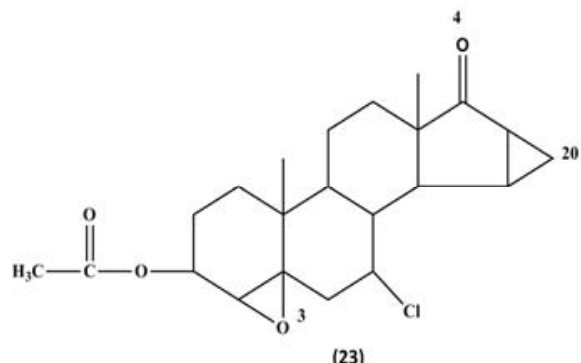

(23)

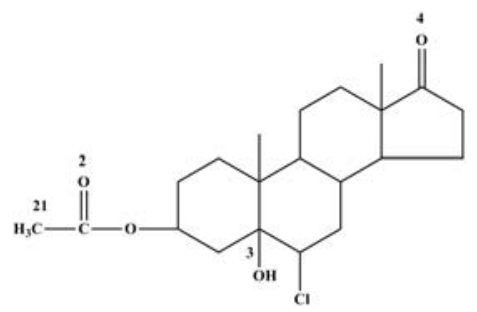

(25)<smiles>[CH]C(=O)OC1CCC2C3CCC45CC(CCC12C)C3(C)CCC(C)(O)C4O5</smiles>

(18)

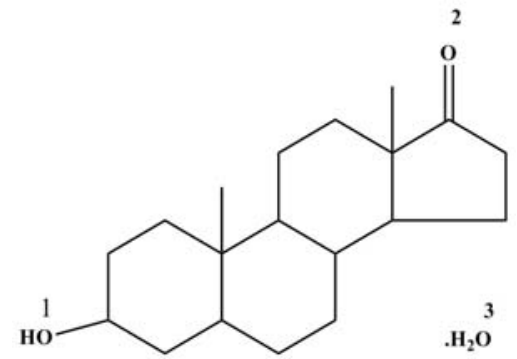

(20)
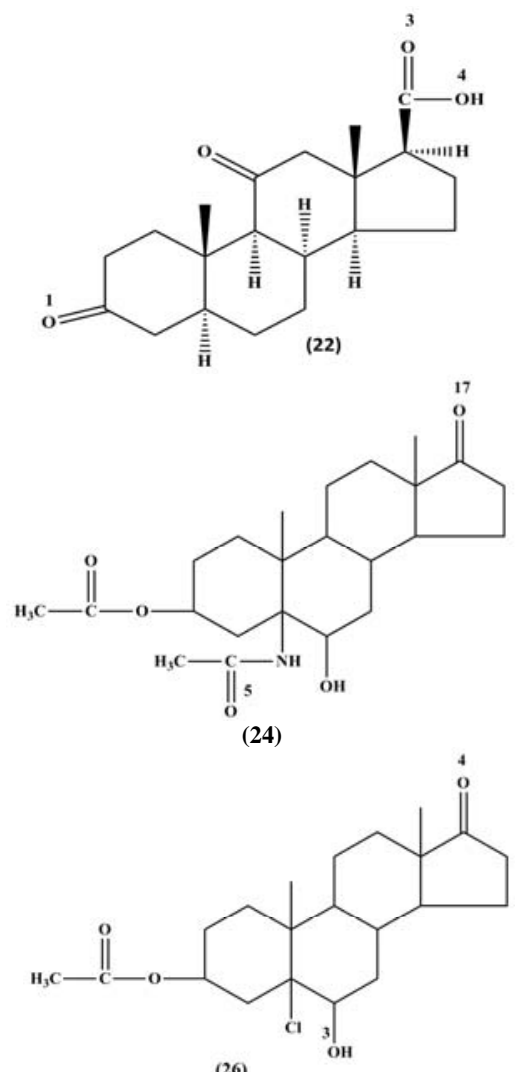
<smiles>CC(=O)OC1CC(OC(C)=O)C23CC24CC(O)CC2C5CCC(=O)C5(C)CCC4C23C1</smiles><smiles>CO[C@H]1CC2C3CC[C@H](OC(C)=O)[C@@]3(C)CCC2[C@@]2(C)CC[C@@H](C)CC12</smiles>

(29)<smiles>CC(=O)OC1CCC2(C)C(C1)C(F)CC1C3CCC(=O)C3(C)CCC12</smiles>

(31)<smiles>CN(C)C1CC2C3CCC(=O)C3(C)CCC2C2(C)CCC(=O)CC12</smiles>

(33)<smiles>CC(=O)OC1CCC2(C)C3CCC4(C)C(=O)CCC4C3CC(O)C2(Br)C1</smiles>

(35)<smiles>C[C@]12CC[C@]3(C)[C@]4(C)CCC(=O)CC4CC[C@@]3(C)[C@@]1(C)CC[C@@]2(C)O</smiles>

(28)<smiles>COC1CC2C(CCC3(C)C(OC(C)=O)CC[C@]23O)C2(C)CCC(OC(C)=O)CC12</smiles>

(30)

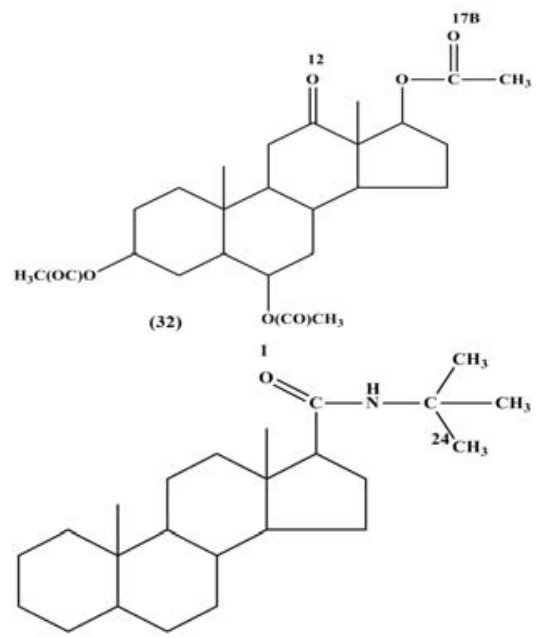

(34)

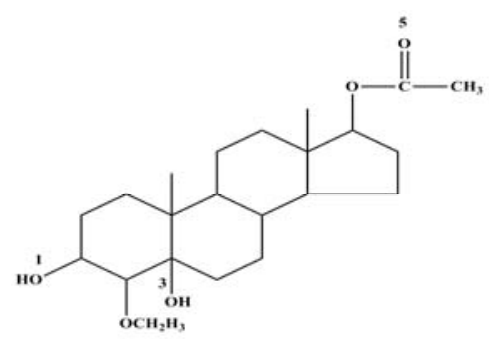

(36) 


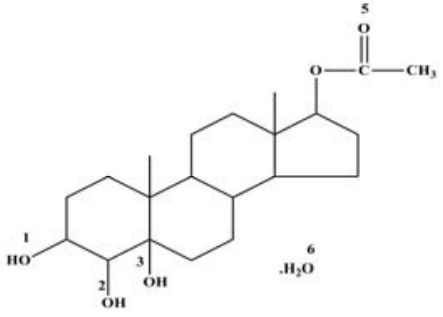

(37)

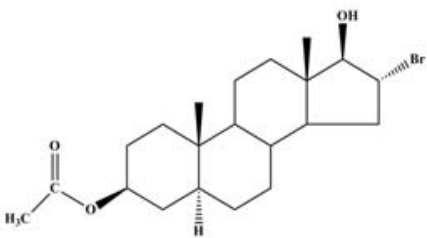

(39)

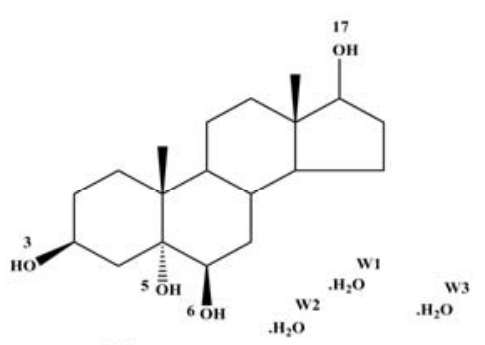

(41)

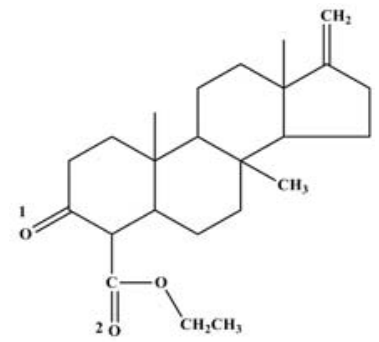

(43)<smiles>[CH]OC12CC(OC(C)=O)CCC1(C)C1CCC3(C)C(=O)CCC3C1CC2O</smiles>

(38)

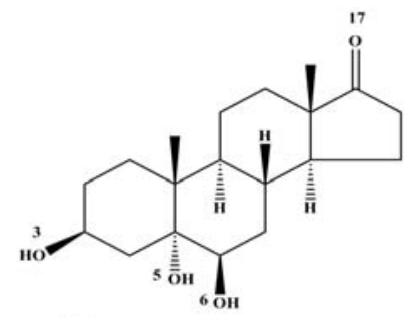

(40)

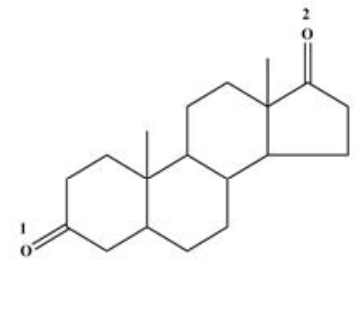

(42)

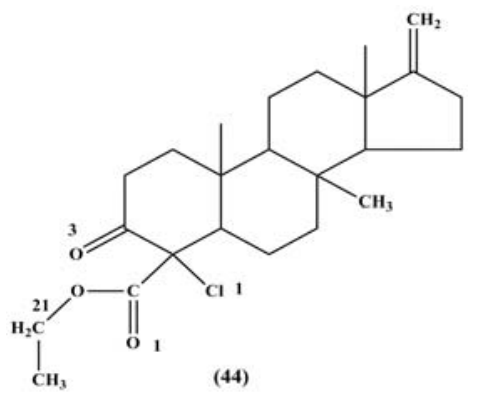

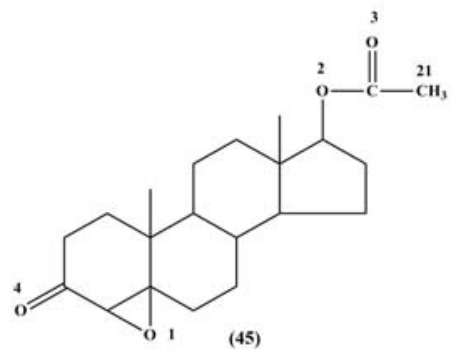

Figure 2. Chemical structures of molecules (1-45) 
Table 1. CSD code, chemical name, chemical formula, molecular wt. and reference of molecules (1-45)

\begin{tabular}{|c|c|c|c|c|c|}
\hline$\frac{0}{\overrightarrow{0}}$ & 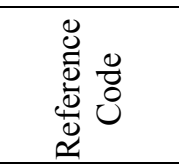 & Chemical Name & 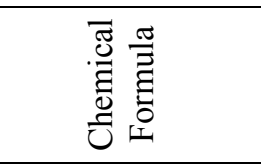 & 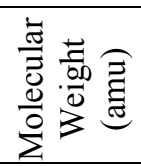 & 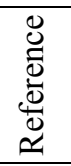 \\
\hline M-1 & LOSNAI & $\begin{array}{c}\text { trans-anti-trans-anti-cis- } \\
\text { 4,17-Dioxoandrostane- } 8 \text { - } \\
\text { carboxylic acid methyl Ester }\end{array}$ & $\mathrm{C}_{21} \mathrm{H}_{30} \mathrm{O}_{4}$ & 346.45 & (a) \\
\hline M-2 & MOVFOS & 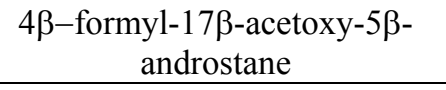 & $\mathrm{C}_{22} \mathrm{H}_{34} \mathrm{O}_{3}$ & 346.49 & (b) \\
\hline M-3 & GURFEE & $\begin{array}{c}9 \alpha \text {-Chloro- } 3 \beta, 11 \beta \text {-dihydroxy } \\
-5 \alpha \text {-androstan-17-one }\end{array}$ & $\mathrm{C}_{19} \mathrm{H}_{29} \mathrm{Cl}_{1} \mathrm{O}_{3}$ & 340.87 & (c) \\
\hline M-4 & MOSYEY & $\begin{array}{c}\text { rac- }(5 \beta, 8 \alpha, 9 \alpha, 10 \beta, 13 \alpha, 14 \alpha)- \\
\text { Methyl } 14 \text {-hydroxy-1,7,17- } \\
\text { trioxoandrostane-10- } \\
\text { carboxylate }\end{array}$ & $\mathrm{C}_{20} \mathrm{H}_{26} \mathrm{O}_{6}$ & 362.41 & (d) \\
\hline M-5 & IKIRID & $\begin{array}{c}3 \alpha, 6 \beta, 17 \beta \text {-Trihydroxy- } 5 \beta- \\
\text { androstane monohydrate }\end{array}$ & $\mathrm{C}_{19} \mathrm{H}_{32} \mathrm{O}_{3}, \mathrm{H}_{2} \mathrm{O}_{1}$ & 326.46 & (e) \\
\hline M-6 & VADWAZ & $\begin{array}{c}3 \alpha, 4 \beta \text {-Dihydroxy- } 5 \beta- \\
\text { androstan-17-one }\end{array}$ & $\mathrm{C}_{19} \mathrm{H}_{30} \mathrm{O}_{3}$ & 306.43 & (f) \\
\hline M-7 & AKAJUR & $\begin{array}{l}\text { methyl 1,8-dimethyl-7,16- } \\
\text { dioxoandrostan-19-oate }\end{array}$ & $\mathrm{C}_{21} \mathrm{H}_{28} \mathrm{O}_{5}$ & 360.43 & (g) \\
\hline M-8 & IZAXEM & 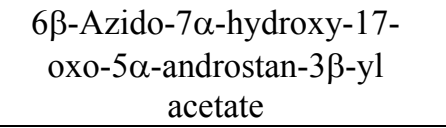 & $\mathrm{C}_{21} \mathrm{H}_{31} \mathrm{~N}_{3} \mathrm{O}_{4}$ & 389.49 & (i) \\
\hline M-9 & LAFCOL & 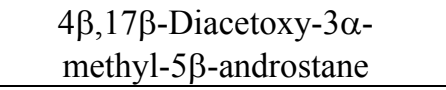 & $\mathrm{C}_{24} \mathrm{H}_{38} \mathrm{O}_{4}$ & 390.54 & (j) \\
\hline M-10 & XAMCAQ & 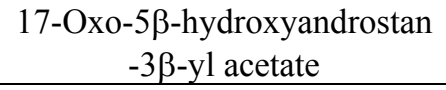 & $\mathrm{C}_{21} \mathrm{H}_{32} \mathrm{O}_{4}$ & 348.47 & $(\mathrm{k})$ \\
\hline M-11 & XAPXIW & $\begin{array}{l}15 \alpha \text {-Hydroxy-1 } \alpha \text {-methyl- } \\
5 \alpha \text {-androstane-3,17-dione }\end{array}$ & $\mathrm{C}_{20} \mathrm{H}_{30} \mathrm{O}_{3}$ & 318.44 & (l) \\
\hline M-12 & KESKAV & 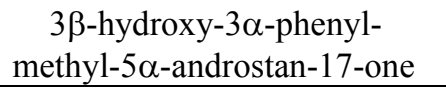 & $\mathrm{C}_{26} \mathrm{H}_{36} \mathrm{O}_{2}$ & 380.548 & (m) \\
\hline M-13 & LAPRUQ & 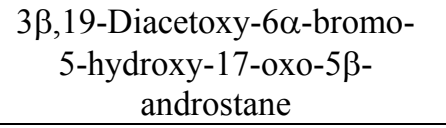 & $\mathrm{C}_{23} \mathrm{H}_{33} \mathrm{Br}_{1} \mathrm{O}_{6}$ & 485.4 & (n) \\
\hline M-14 & FEFKEH & $\begin{array}{l}\text { 17-Oxo- } 5 \alpha \text {-androstane- } \\
3 \alpha, 4 \beta \text {-diyl diacetate } \\
\text { unknown solvate }\end{array}$ & $\mathrm{C}_{23} \mathrm{H}_{34} \mathrm{O}_{5}$ & 390.50 & (o) \\
\hline M-15 & FEFROY & $\begin{array}{c}\text { 17-Oxo-5 } \beta \text {-androstane- } \\
3 \alpha, 4 \beta \text {-diyl diacetate }\end{array}$ & $\mathrm{C}_{23} \mathrm{H}_{34} \mathrm{O}_{5}$ & 390.50 & (p) \\
\hline M-16 & FIRXOU & $\begin{array}{c}3 \beta, 17 \beta \text {-Dihydroxy- } 4 \alpha, 5 \alpha- \\
\text { epoxy-3 } \alpha \text {-methylandrostane } \\
\text { monohydrate }\end{array}$ & $\mathrm{C}_{20} \mathrm{H}_{32} \mathrm{O}_{3}, \mathrm{H}_{2} \mathrm{O}_{1}$ & 338.47 & (q) \\
\hline
\end{tabular}




\begin{tabular}{|c|c|c|c|c|c|}
\hline M-17 & FIRXIO & 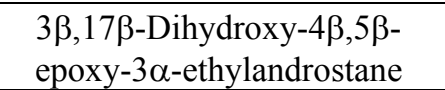 & $\mathrm{C}_{21} \mathrm{H}_{34} \mathrm{O}_{3}$ & 334.48 & (r) \\
\hline M-18 & FIRXUA & 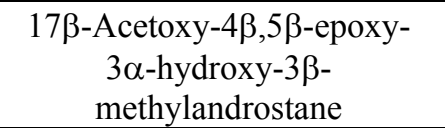 & $\mathrm{C}_{22} \mathrm{H}_{34} \mathrm{O}_{4}$ & 362.49 & (s) \\
\hline M-19 & FIRXUA01 & 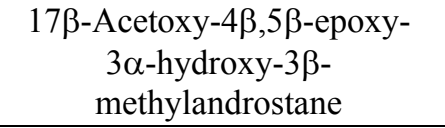 & $\mathrm{C}_{22} \mathrm{H}_{34} \mathrm{O}_{4}$ & 362.49 & $(\mathrm{t})$ \\
\hline M-20 & ANDOON05 & $\begin{array}{c}5 \alpha \text {-Androstane-3 } \alpha \text {-ol-17- } \\
\text { one hemihydrates }\end{array}$ & $\begin{array}{c}\mathrm{C}_{19} \mathrm{H}_{30} \\
\mathrm{O}_{2}, 0.5\left(\mathrm{H}_{2} \mathrm{O}_{1}\right) \\
\end{array}$ & 598.88 & (u) \\
\hline $\mathrm{M}-21$ & ANDOON06 & $5 \alpha$-Androstane-3 $\alpha$-ol-17-one & $\mathrm{C}_{19} \mathrm{H}_{30} \mathrm{O}_{2}$ & 290.43 & (v) \\
\hline M-22 & CELKUA & $\begin{array}{c}(+)-3,11-\text { Dioxo-5 } \alpha- \\
\text { androstanecarboxylic acid }\end{array}$ & $\mathrm{C}_{20} \mathrm{H}_{28} \mathrm{O}_{4}$ & 332.42 & (w) \\
\hline M-23 & QEXPEP & 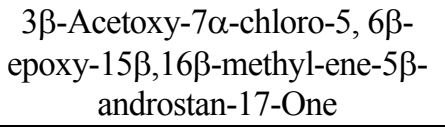 & $\mathrm{C}_{22} \mathrm{H}_{29} \mathrm{Cl}_{1} \mathrm{O}_{4}$ & 392.90 & $(\mathrm{x})$ \\
\hline M-24 & MIGTAY & 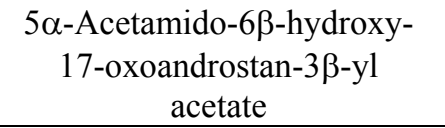 & $\mathrm{C}_{23} \mathrm{H}_{35} \mathrm{~N}_{1} \mathrm{O}_{5}$ & 405.52 & (y) \\
\hline M-25 & XEYTOL & $\begin{array}{l}3 \beta \text {-Acetoxy- } 6 \alpha \text {-chloro- } 5 \beta \text { - } \\
\text { hydroxyandrostan-17-one }\end{array}$ & $\mathrm{C}_{21} \mathrm{H}_{31} \mathrm{Cl}_{1} \mathrm{O}_{4}$ & 382.91 & $(\mathrm{z})$ \\
\hline M-26 & XIFSIP & $\begin{array}{l}3 \beta \text {-Acetoxy- } 5 \alpha \text {-chloro- } 6 \beta \text { - } \\
\text { hydroxyandrostan-17-one }\end{array}$ & $\mathrm{C}_{21} \mathrm{H}_{31} \mathrm{Cl}_{1} \mathrm{O}_{4}$ & 382.91 & (aa) \\
\hline M-27 & XIGHOL & $\begin{array}{c}\text { 5,19-Cyclo-1 } \alpha, 3 \beta- \\
\text { diacetoxy-6 } \beta \text { - } \\
\text { hydroxyandrostan-17-one }\end{array}$ & $\mathrm{C}_{23} \mathrm{H}_{32} \mathrm{O}_{6}$ & 404.49 & $(\mathrm{ab})$ \\
\hline M-28 & YOFWOG & $\begin{array}{c}17 \beta \text {-Hydroxy-17 } \alpha \text {-methyl- } \\
5 \alpha \text {-androstan-3-one }\end{array}$ & $\mathrm{C}_{20} \mathrm{H}_{32} \mathrm{O}_{2}$ & 304.47 & (ac) \\
\hline M-29 & EGAHEA & $\begin{array}{c}3 \beta, 6 \alpha, 17 \beta \text {-Triacetoxy-5 } \alpha- \\
\text { androstane }\end{array}$ & $\mathrm{C}_{25} \mathrm{H}_{38} \mathrm{O}_{6}$ & 434.55 & (ad) \\
\hline M-30 & EGAHIE & $\begin{array}{l}3 \beta, 6 \alpha, 17 \beta \text {-Triacetoxy- } 5 \alpha- \\
\text { androstan- } 14 \alpha \text {-ol }\end{array}$ & $\mathrm{C}_{25} \mathrm{H}_{38} \mathrm{O}_{7}$ & 450.55 & (ae) \\
\hline M-31 & AGAVEK & 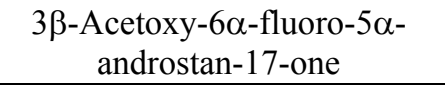 & $\mathrm{C}_{21} \mathrm{H}_{31} \mathrm{~F}_{1} \mathrm{O}_{3}$ & 350.46 & (af) \\
\hline M-32 & EHAKAA & $\begin{array}{l}3 \beta, 6 \alpha, 17 \beta \text {-Triacetoxy-5 } \alpha \text { - } \\
\text { androstan-12-one }\end{array}$ & $\mathrm{C}_{25} \mathrm{H}_{36} \mathrm{O}_{7}$ & 448.54 & (ag) \\
\hline M-33 & YOPYIM & $\begin{array}{l}4 \alpha \text {-(Dimethylamino)-5 } \alpha \text { - } \\
\text { androstane-3,17-dione }\end{array}$ & $\mathrm{C}_{21} \mathrm{H}_{33} \mathrm{~N}_{1} \mathrm{O}_{2}$ & 331.48 & (ah) \\
\hline M-34 & EHABUL & $\begin{array}{c}\text { (5R,8R,9S,10S,13S,14S,17S) } \\
\text {-N-t-Butyl-5 } \alpha \text {-androstane- } \\
\text { 17 } \beta \text {-Carboxamide }\end{array}$ & $\mathrm{C}_{24} \mathrm{H}_{41} \mathrm{~N}_{1} \mathrm{O}_{1}$ & 359.58 & (ai) \\
\hline M-35 & LALCEI & $\begin{array}{l}3 \beta \text {-Acetoxy- } 5 \alpha \text {-bromo- } 6 \beta- \\
\text { hydroxyandrostan-17-one }\end{array}$ & $\mathrm{C}_{21} \mathrm{H}_{31} \mathrm{Br}_{1} \mathrm{O}_{4}$ & 427.36 & (aj) \\
\hline
\end{tabular}




\begin{tabular}{|c|c|c|c|c|c|}
\hline M-36 & GAFSEN & $\begin{array}{c}\text { 4 } \beta \text {-Ethoxy- } 3 \beta, 5 \alpha \text {-dihy- } \\
\text { droxyandrostan- } 17 \beta \text {-yl acetate }\end{array}$ & $\mathrm{C}_{23} \mathrm{H}_{38} \mathrm{O}_{5}$ & 394.53 & (ak) \\
\hline M-37 & LAWBIW & $\begin{array}{c}3 \beta, 4 \beta, 5 \alpha- \\
\text { Trihydroxyandrostan-17ß-yl } \\
\text { acetate monohydrate }\end{array}$ & $\mathrm{C}_{21} \mathrm{H}_{34} \mathrm{O}_{5}, \mathrm{H}_{2} \mathrm{O}_{1}$ & 384.5 & (al) \\
\hline M-38 & GAFSOX & $\begin{array}{l}5 \alpha \text {-Ethoxy- } 6 \beta \text {-hydroxy-17- } \\
\text { oxoandrostan- } 3 \beta \text {-yl acetate }\end{array}$ & $\mathrm{C}_{23} \mathrm{H}_{36} \mathrm{O}_{5}$ & 392.52 & (am) \\
\hline M-39 & KUSNES & 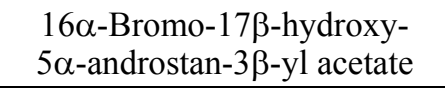 & $\mathrm{C}_{21} \mathrm{H}_{33} \mathrm{Br}_{1} \mathrm{O}_{3}$ & 413.38 & (an) \\
\hline M-40 & URAJON & $\begin{array}{c}3 \beta, 5 \alpha, 6 \beta- \\
\text { Trihydroxyandrostan-17-one }\end{array}$ & $\mathrm{C}_{19} \mathrm{H}_{30} \mathrm{O}_{4}$ & 322.43 & (ao) \\
\hline M-41 & EVARUP & $\begin{array}{l}\text { Androstane- } 3 \beta, 5 \alpha, 6 \beta, 17 \beta- \\
\text { tetrol trihydrate }\end{array}$ & $\begin{array}{c}\mathrm{C}_{19} \mathrm{H}_{32} \mathrm{O}_{4}, 3\left(\mathrm{H}_{2}\right. \\
\left.\mathrm{O}_{1}\right) \\
\end{array}$ & 378.49 & (ap) \\
\hline M-42 & CIGQAM & $(+)$-Androstane-3,17-dione & $\mathrm{C}_{19} \mathrm{H}_{28} \mathrm{O}_{2}$ & 288.41 & $(\mathrm{aq})$ \\
\hline M-43 & RETKOS & $\begin{array}{l}\text { Ethyl 8-methyl-17- } \\
\text { methylene-3-oxoandrostane- } \\
\text { 4-carboxylate }\end{array}$ & $\mathrm{C}_{24} \mathrm{H}_{36} \mathrm{O}_{3}$ & 372.53 & (ar) \\
\hline M-44 & RETKUY & $\begin{array}{l}\text { Ethyl 4-chloro-8-methyl-17- } \\
\text { methylene-3-oxoandrostane- } \\
\text { 4-carboxylate }\end{array}$ & $\mathrm{C}_{24} \mathrm{H}_{35} \mathrm{Cl}_{1} \mathrm{O}_{3}$ & 406.97 & (as) \\
\hline M-45 & ZILKEM & $\begin{array}{l}17 \beta \text {-acetoxy- } 4,5 \text {-epoxy-5 } \alpha \text { - } \\
\text { androstan-3-one }\end{array}$ & $\mathrm{C}_{21} \mathrm{H}_{30} \mathrm{O}_{4}$ & 346.45 & (at) \\
\hline
\end{tabular}

\section{Comparative geometrical parameters}

\section{Bond distances and bond angles}

Most of the molecules in the present study have substituents at the $\mathrm{C} 3$, followed by $\mathrm{C} 4$ and $\mathrm{C} 6$ positions. The substituents at these positions of the steroid nucleus causes significant changes in bond distances in ring $\mathrm{A}$ and $\mathrm{B}$, depending upon whether the bond $\mathrm{C} 2-\mathrm{C} 3 / \mathrm{C} 3-$ $\mathrm{C} 4, \mathrm{C} 3-\mathrm{C} 4 / \mathrm{C} 4-\mathrm{C} 5, \mathrm{C} 5-\mathrm{C} 6 / \mathrm{C} 6-\mathrm{C} 7$ is single or double in nature. Therefore, it is of interest to investigate the bond lengths $\mathrm{C} 2-\mathrm{C} 3, \mathrm{C} 3-\mathrm{C} 4, \mathrm{C} 4-\mathrm{C} 5, \mathrm{C} 5-\mathrm{C} 6$ and $\mathrm{C} 6-\mathrm{C} 7$ and the bond angles $\mathrm{C} 2-\mathrm{C} 3-\mathrm{C} 4, \mathrm{C} 3-\mathrm{C} 4-\mathrm{C} 5$ and $\mathrm{C} 5-\mathrm{C} 6-\mathrm{C} 7$, respectively (Table 2$)$. The bond distances $\mathrm{C} 2\left(\mathrm{sp}^{3}\right)-$ $\mathrm{C} 3\left(\mathrm{sp}^{3}\right)$ lie in the range $1.492-1.540 \AA$ (average $=1.514 \AA$ ) but for the molecules 23 $(1.492 \AA)$ and $39(1.495 \AA)\left[39^{\prime}(1.494 \AA)\right]$ have values shorter than the standard value of $1.533 \AA^{51}$. The bond distances $\mathrm{C} 3\left(\mathrm{sp}^{3}\right)-\mathrm{C} 4\left(\mathrm{sp}^{3}\right)$ lie in the range $1.493-1.541 \AA$ (average value $1.516 \AA$ ). However, these values in case of molecule $29(1.497 \AA)$ and $35(1.493 \AA)$ are significantly different ${ }^{42}$ from the accepted value of $1.533 \AA$. The deviation of bond distances $\mathrm{C} 2\left(\mathrm{sp}^{3}\right)-\mathrm{C} 3\left(\mathrm{sp}^{3}\right)$ and $\mathrm{C} 3\left(\mathrm{sp}^{3}\right)-\mathrm{C} 4\left(\mathrm{sp}^{3}\right)$ could be due to the effect of functional groups located at $\mathrm{C} 3$ which invariably are involved in $\mathrm{C}-\mathrm{H}$...O/O-H...O intra/intermolecular interactions. The $\mathrm{C} 2\left(\mathrm{sp}^{3}\right)-\mathrm{C} 3\left(\mathrm{sp}^{2}\right) / \mathrm{C} 2\left(\mathrm{sp}^{2}\right)-\mathrm{C} 3\left(\mathrm{sp}^{3}\right)$ bond distances in molecules having substitutions at $\mathrm{C} 3$ lie in the range 1.48-1.510 $\AA$ (average value $1.495 \AA$ ), whereas the bond distances $\mathrm{C} 3\left(\mathrm{sp}^{3}\right)-\mathrm{C} 4\left(\mathrm{sp}^{2}\right) / \mathrm{C} 3\left(\mathrm{sp}^{2}\right)-\mathrm{C} 4\left(\mathrm{sp}^{3}\right)$ lie in the range 1.482-1.541 $\AA$ (average value $1.509 \AA$ ). It is probably the involvement of $\mathrm{O}$ atom of the keto group in $\mathrm{C}-\mathrm{H}$...O/O-H...O intra/intermolecular interactions that causes deviation in the corresponding bond distances. The bond distances $\mathrm{C} 5\left(\mathrm{sp}^{3}\right)-\mathrm{C} 6\left(\mathrm{sp}^{3}\right)$ and $\mathrm{C} 6\left(\mathrm{sp}^{3}\right)-\mathrm{C} 7\left(\mathrm{sp}^{3}\right)$ lie in the range 1.454-1.548 $\AA$ (average value $1.526 \AA$ ) and 1.49-1.53 $\AA$ (average value $1.51 \AA$ ), respectively. 
Table 2. C2-C3, C3-C4, C4-C5, C5-C6 and C6-C7 bond distances (Å) and C2-C3-C4, C3C4-C6 and C5-C6-C7 bond angles $\left({ }^{\circ}\right)$ for molecules (1-45)

\begin{tabular}{|c|c|c|c|c|c|c|c|c|c|c|c|c|c|}
\hline \multirow[b]{3}{*}{$\stackrel{\overline{0}}{\Sigma}$} & \multicolumn{8}{|c|}{ Bond Distance $(\AA)$} & \multicolumn{5}{|c|}{ Bond Angle $\left(^{\circ}\right)$} \\
\hline & \multicolumn{2}{|c|}{ [C 2 - C3] } & \multicolumn{2}{|c|}{ [C 3 - C4] } & \multicolumn{2}{|c|}{$[\mathrm{C} 4-\mathrm{C} 5]$} & \multirow{2}{*}{$\begin{array}{l}\text { C5- } \\
\text { C6] } \\
\text { के के }\end{array}$} & \multirow{2}{*}{$\begin{array}{l}\text { [C6- } \\
\text { C7] } \\
\text { के की }\end{array}$} & \multicolumn{2}{|c|}{ C3 } & \multicolumn{2}{|c|}{$\mathrm{C} 4$} & \multirow{2}{*}{$\begin{array}{c}\text { C6 } \\
\text { के }\end{array}$} \\
\hline & $\begin{array}{l}\hat{2} \\
\hat{\sigma}^{1} \\
\hat{n} \\
\hat{2}\end{array}$ & 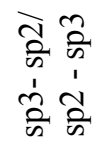 & $\begin{array}{l}\hat{2} \\
\hat{2} \\
1 \\
\hat{2} \\
\hat{n}\end{array}$ & $\begin{array}{l}\text { ते } \\
\text { के के } \\
1 \\
\text { के ते } \\
\text { के के }\end{array}$ & $\begin{array}{l}\text { के } \\
1 \\
\text { के }\end{array}$ & 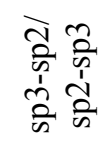 & & & $\hat{n}$ & है & $\hat{n}$ & है & \\
\hline M-1 & - & - & - & 1.496 & - & 1.504 & - & - & - & - & & 115 & - \\
\hline M-2 & - & - & 1.541 & - & 1.539 & - & - & - & - & - & 112 & - & - \\
\hline M-3 & 1.506 & - & 1.517 & - & - & - & - & - & 111 & - & - & - & - \\
\hline M-4 & - & - & 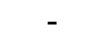 & - & - & - & - & - & - & - & - & - & - \\
\hline M-5 & 1.513 & - & 1.51 & - & - & - & 1.527 & $\begin{array}{c}1.52 \\
4\end{array}$ & 111 & - & - & - & 112 \\
\hline M-6 & 1.513 & - & 1.51 & - & 1.537 & - & - & - & 112 & - & 112 & - & - \\
\hline M-7 & - & - & & - & - & - & - & - & - & - & - & - & - \\
\hline M-8 & 1.507 & - & 1.514 & - & - & - & 1.522 & 1.528 & 112 & - & - & - & 110.7 \\
\hline M-9 & 1.532 & - & 1.518 & - & 1.53 & - & - & - & 109 & - & 115 & - & - \\
\hline M-9' & 1.527 & - & 1.521 & - & 1.538 & - & - & - & 109 & - & 114 & - & - \\
\hline M-10 & 1.513 & - & 1.518 & - & - & - & - & - & 112 & - & - & - & - \\
\hline M-10' & 1.509 & - & 1.514 & - & - & - & - & - & 113 & - & - & - & - \\
\hline M-11 & - & 1.488 & - & 1.487 & - & - & - & - & - & 116 & - & - & - \\
\hline M-12 & 1.527 & - & 1.521 & - & - & - & - & - & 109 & - & - & - & - \\
\hline M-12' & 1.531 & - & 1.526 & - & - & - & - & - & 109 & - & - & - & - \\
\hline M-13 & 1.521 & - & 1.509 & - & - & - & 1.545 & 1.522 & 112 & - & - & - & 115.1 \\
\hline M-14 & 1.511 & - & 1.52 & - & 1.523 & - & - & - & 112 & - & 113 & - & - \\
\hline M-15 & 1.502 & - & 1.505 & - & 1.529 & - & - & - & 112 & - & 113 & - & - \\
\hline M-16 & 1.54 & - & 1.522 & - & - & - & - & - & 112 & - & - & - & - \\
\hline M-17 & 1.531 & - & 1.521 & - & 1.49 & - & - & - & 111 & - & 123 & - & - \\
\hline M-17' & 1.537 & - & 1.52 & - & 1.478 & - & - & - & 112 & - & 124 & - & - \\
\hline M-18 & 1.53 & - & 1.523 & - & - & - & - & - & 112 & - & - & - & - \\
\hline M-19 & 1.507 & - & 1.514 & - & - & - & - & - & 112 & - & - & - & - \\
\hline M-20 & 1.519 & - & 1.521 & - & - & - & - & - & 110 & - & - & - & - \\
\hline M-20' & 1.521 & - & 1.515 & - & - & - & - & - & 111 & - & - & - & - \\
\hline M-21 & 1.507 & - & 1.525 & - & - & - & - & - & 111 & - & - & - & - \\
\hline M-22 & - & 1.5 & & 1.504 & - & - & - & - & - & 116 & - & - & - \\
\hline M-23 & 1.492 & - & 1.503 & - & - & - & 1.454 & 1.49 & 110 & - & - & - & 121.2 \\
\hline M-24 & 1.517 & - & 1.52 & - & - & - & 1.548 & 1.515 & 113 & - & - & - & 111.5 \\
\hline M-25 & 1.51 & - & 1.509 & - & - & - & 1.52 & 1.502 & 112 & - & - & - & 114.7 \\
\hline M-26 & 1.519 & - & 1.507 & - & - & - & $1 . .530$ & 1.515 & 113 & - & - & - & 111.7 \\
\hline M-26' & 1.509 & - & 1.515 & - & - & - & 1.532 & 1.523 & 113 & - & - & - & 111.6 \\
\hline M-27 & 1.51 & - & 1.513 & - & - & - & 1.526 & 1.524 & 112 & - & - & - & 113.8 \\
\hline M-28 & - & 1.499 & & 1.499 & - & - & - & - & - & 116 & & - & - \\
\hline M-29 & 1.501 & - & 1.497 & - & - & - & 1.519 & 1.51 & 112 & - & - & - & 111.8 \\
\hline M-30 & 1.506 & & 1.519 & & & & 1.513 & 1.511 & 111 & & & & 112.1 \\
\hline
\end{tabular}




\begin{tabular}{cccccccccccccc}
\hline M-31 & 1.518 & & 1.522 & & & & 1.524 & 1.516 & 112 & & & & 112.1 \\
M-32 & 1.508 & - & 1.514 & - & - & - & 1.526 & 1.511 & 111 & - & - & - & 111.2 \\
M-33 & - & 1.5 & - & 1.533 & - & - & - & - & - & 116 & - & - & - \\
M-34 & - & - & - & - & - & - & - & - & - & - & - & - & - \\
M-35 & 1.519 & - & 1.493 & - & - & - & 1.541 & 1.53 & 114 & - & - & - & 112.2 \\
M-35 & 1.517 & - & 1.527 & - & - & - & 1.541 & 1.494 & 111 & - & - & - & 111.5 \\
M-36 & 1.509 & - & 1.528 & - & 1.525 & - & - & - & 111 & - & 111 & - & - \\
M-37 & 1.522 & - & 1.522 & - & 1.535 & - & - & - & 112 & - & 113 & - & - \\
M-38 & 1.524 & - & 1.52 & - & - & - & 1.54 & 1.514 & 112 & - & - & - & 111.5 \\
M-39 & 1.495 & - & 1.514 & - & - & - & - & - & 112 & - & - & - & - \\
M-39 & 1.494 & - & 1.518 & - & - & - & - & - & 113 & - & - & & - \\
M-40 & 1.51 & - & 1.518 & - & - & - & 1.533 & 1.522 & 112 & - & - & & 111 \\
M-41 & 1.513 & - & 1.52 & - & - & - & 1.535 & 1.52 & 112 & - & - & & 110.4 \\
M-42 & - & 1.513 & - & 1.51 & - & - & - & - & - & 111 & - & - & - \\
M-43 & - & 1.5 & - & 1.534 & - & - & - & - & - & 115 & - & - & - \\
M-44 & - & 1.48 & - & 1.541 & 1.544 & - & - & - & - & 114 & 114 & - & - \\
M-45 & - & 1.502 & - & 1.482 & 1.481 & - & - & - & - & 119 & 120 & - & - \\
\hline
\end{tabular}

indicates the absence of a particular bond/angle; ' indicates second independent molecule

The substitution of a group at the $\mathrm{C} 3$ position also causes a significant change in the value of bond angle $\mathrm{C} 2-\mathrm{C} 3-\mathrm{C} 4$ in ring $\mathrm{A}$, depending upon whether $\mathrm{C} 3$ is $\mathrm{sp}^{3}$ or $\mathrm{sp}^{2}$ hybridized. The bond angle $\mathrm{C} 2-\mathrm{C} 3-\mathrm{C} 4$ in molecules with a substituent at the $\mathrm{C} 3\left(\mathrm{sp}^{3}\right)$ position varies from 108.89 to $112.95\left(^{\circ}\right)$ (average being $111.57\left({ }^{\circ}\right)$ ). The bond angle $\mathrm{C} 2-\mathrm{C} 3-$ $\mathrm{C} 4$ with $\mathrm{C} 3\left(\mathrm{sp}^{3}\right)$ in all molecules except $3\left(110.6^{\circ}\right), 5\left(110.73^{\circ}\right), 9\left(108.89^{\circ}\right)\left[9^{\prime}\left(109.16^{\circ}\right)\right]$ $12\left(109.49^{\circ}\right),\left[12^{\prime}\left(109.33^{\circ}\right)\right], 20\left(110.3^{\circ}\right)$ and $21\left(110.8^{\circ}\right)$ shows a significant deviation from the tetrahedral value of $109.46^{\circ}$. The deviation in the $\mathrm{C} 2-\mathrm{C} 3-\mathrm{C} 4$ bond angle in these molecules is caused by $\mathrm{O}-\mathrm{H}$...O intermolecular interactions, which are probably due to the presence of different groups at the $\mathrm{C} 3$ position. The bond angle $\mathrm{C} 2-\mathrm{C} 3\left(\mathrm{sp}^{2}\right)-\mathrm{C} 4$ in molecules with a substituent at the $\mathrm{C} 3$ position varies from 110.73 to $118.52^{\circ}$ (average value $\left.115.09^{\circ}\right)$. The bond angle $\mathrm{C} 2-\mathrm{C} 3\left(\mathrm{sp}^{2}\right)-\mathrm{C} 4$ in molecules $42\left(110.73^{\circ}\right), 43\left(114.95^{\circ}\right)$, $44\left(113.6^{\circ}\right)$, shows some deviation from the value of $120.0^{\circ}$ for $\mathrm{sp}^{2}$-type hybridization. The presence of a ketone group makes the $\mathrm{C} 2-\mathrm{C} 3-\mathrm{C} 4$ bond angle deviate significantly and it also results in the occurrence of $\mathrm{C}-\mathrm{H}$...O/O-H...O intra- and intermolecular interactions. The bond angle $\mathrm{C} 5-\mathrm{C} 6-\mathrm{C} 7 \mathrm{in}$ molecules with a substituent at the $\mathrm{C} 6\left(\mathrm{sp}^{3}\right)$ position varies from 110.36 to $115.1^{\circ}$ (average value $112.55^{\circ}$ ).

\section{Ring conformations and their graphical representations}

Asymmetry parameters $\left(\Delta \mathrm{C}_{2} \text { and } \Delta \mathrm{C}_{\mathrm{S}}\right)^{43}$ play an important role in describing the conformation of five- and six-membered moieties of steroidal molecules. The asymmetry parameters have been calculated for the individual ring systems of all the molecules (1-45) and their detailed analysis shows the existence of different types of conformations. These conformations as obtained for individual ring systems are presented in Table 3.

The following observations can be made from the different ring conformations as adopted by individual ring systems of molecules (1-45): The incidence of occurrence of a chair conformation in ring A is quite large (83.01\%). Ring A in molecule (16), (17)' and (18) occurs in the sofa conformation with asymmetric parameters $\left(\Delta \mathrm{C}_{2}=23.04, \Delta \mathrm{C}_{\mathrm{S}}=4.97\right),\left(\Delta \mathrm{C}_{2}=\right.$ $\left.21.70, \Delta \mathrm{C}_{\mathrm{S}}=6.314\right),\left(\Delta \mathrm{C}_{2}=22.50, \Delta \mathrm{C}_{\mathrm{S}}=5.81\right)$ respectively, although these are saturated rings. This type of behaviour by the saturated rings may be due to the presence of an epoxy 
ring between $\mathrm{C} 4$ and $\mathrm{C} 5$. Ring A and $\mathrm{B}$ of molecule (27) adopts half-chair conformation which may be due to the presence of a cyclopropane ring between $\mathrm{C} 5$ and $\mathrm{C} 10$. In most of the molecules, ring $\mathrm{B}$ adopts chair conformation. The incidence of occurrence of a chair conformation in ring $\mathrm{C}$ is quite large. Ring $\mathrm{D}$ adopts different conformations (envelope, halfchair and intermediate between the two) in different molecules.

Table 3. Different types of conformations in the individual ring systems (molecules 1-45)

\begin{tabular}{|c|c|c|c|c|}
\hline Molecule & $\begin{array}{c}\text { Ring A } \\
\text { (conformation) }\end{array}$ & $\begin{array}{c}\text { Ring B } \\
\text { (conformation) }\end{array}$ & $\begin{array}{c}\text { Ring C } \\
\text { (conformation) }\end{array}$ & $\begin{array}{c}\text { Ring D } \\
\text { (conformation) }\end{array}$ \\
\hline M-1 & Chair & Chair & Distorted Chair & $\begin{array}{l}\text { Intermediate between } \\
\text { envelope and Half- chair }\end{array}$ \\
\hline M-2 & Chair & Chair & Chair & Half- chair \\
\hline M-3 & Chair & Chair & Chair & Envelope \\
\hline M-4 & Chair & Chair & Distorted chair & Envelope \\
\hline M-5 & Chair & Chair & Chair & Half-chair \\
\hline M-6 & Chair & Chair & Chair & Half- chair \\
\hline M-7 & Distorted chair & Chair & Distorted chair & Half- chair \\
\hline M-8 & Chair & Chair & Chair & Envelope \\
\hline M-9 & Chair & Chair & Chair & Half- chair \\
\hline M-9' & Chair & Chair & Chair & Half- chair \\
\hline M-10 & Chair & Chair & Chair & $\begin{array}{l}\text { Intermediate between } \\
\text { envelope and half-chair }\end{array}$ \\
\hline M-10' & Chair & Chair & Chair & Envelope \\
\hline M-11 & Chair & Chair & Chair & Half-chair \\
\hline M-12 & Chair & Chair & Chair & Envelope \\
\hline M-12' & Chair & Chair & Chair & Envelope \\
\hline M-13 & Chair & Chair & Chair & Envelope \\
\hline M-14 & Chair & Chair & Chair & $\begin{array}{l}\text { Intermediate between } \\
\text { envelope and half-chair }\end{array}$ \\
\hline M-15 & Chair & Chair & Chair & Envelope \\
\hline M-16 & Sofa & Chair & Chair & Envelope \\
\hline M-17 & Half-chair & Chair & Chair & Envelope \\
\hline M-17' & Sofa & Chair & Chair & Envelope \\
\hline M-18 & Sofa & Chair & Chair & Envelope \\
\hline M-19 & $\begin{array}{l}\text { Intermediate } \\
\text { between envelope } \\
\text { and half-chair }\end{array}$ & Chair & Chair & Envelope \\
\hline M-20 & Chair & Chair & Chair & Envelope \\
\hline M-20' & Chair & Half-chair & Chair & Envelope \\
\hline M-21 & Chair & Chair & Chair & Half-chair \\
\hline M-22 & Chair & Chair & Chair & Half-chair \\
\hline M-23 & Distorted chair & Sofa & Chair & Envelope \\
\hline M-24 & Chair & Chair & Chair & Envelope \\
\hline M-25 & Chair & Chair & Chair & Distorted Envelope \\
\hline M-26 & Chair & Chair & Chair & Envelope \\
\hline M-26' & Chair & Chair & Chair & $\begin{array}{l}\text { Intermediate between } \\
\text { envelope and half-chair }\end{array}$ \\
\hline
\end{tabular}




\begin{tabular}{|c|c|c|c|c|}
\hline M-27 & Half-chair & Half-chair & Chair & Envelope \\
\hline M-28 & Chair & Chair & Chair & Half-chair \\
\hline M-29 & Chair & Chair & Chair & Envelope \\
\hline M-30 & Chair & Chair & Chair & $\begin{array}{l}\text { Intermediate between } \\
\text { envelope and half-chair }\end{array}$ \\
\hline M-31 & Chair & Chair & Chair & Envelope \\
\hline M-32 & Chair & Chair & Chair & Envelope \\
\hline M-33 & Chair & Chair & Chair & Envelope \\
\hline M-34 & Chair & Chair & Chair & Half-chair \\
\hline M-35 & Chair & Chair & Chair & Envelope \\
\hline M-35' & Chair & Chair & Chair & Envelope \\
\hline M-36 & Chair & Chair & Chair & Envelope \\
\hline M-37 & Chair & Chair & Chair & Envelope \\
\hline M-38 & Chair & Chair & Chair & Envelope \\
\hline M-39 & Chair & Chair & Chair & Envelope \\
\hline M-39' & Chair & Chair & Chair & Envelope \\
\hline $\mathrm{M}-40$ & Chair & Chair & Chair & Envelope \\
\hline M-41 & Chair & Chair & Chair & $\begin{array}{l}\text { Intermediate between } \\
\text { envelope and half-chair }\end{array}$ \\
\hline M-42 & Chair & Chair & Chair & Envelope \\
\hline M-43 & Chair & Chair & Chair & $\begin{array}{l}\text { Intermediate between } \\
\text { envelope and half-chair }\end{array}$ \\
\hline M-44 & Chair & Chair & Distorted chair & Half-chair \\
\hline M-45 & Half-chair & Chair & Chair & $\begin{array}{l}\text { Intermediate between } \\
\text { envelope and half-chair }\end{array}$ \\
\hline
\end{tabular}

The relative frequency of various types of conformations occurring in six-membered and five-membered rings in molecules (1-45) are shown in Figure 3(a,b). The incidence of occurrence of the three six-membered rings in the chair conformation (normal as well as distorted-chair) is $93.08 \%$, followed by the half-chair and sofa conformations $(3.14 \%$ and $2.50 \%$, respectively). Similarly, for the five membered rings, the incidence of occurrence of (envelope and distorted envelope) conformation is $62.2 \%$, followed by half-chair and intermediate between half-chair and envelope conformations (22.6 and 15.0\%, respectively).

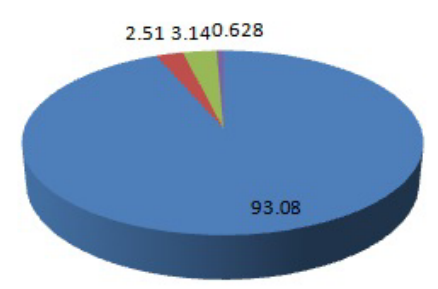

(a)

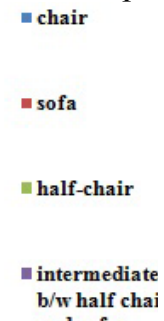

and sofa

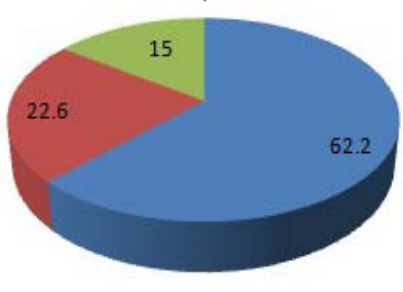

(b) in envelupe

nalf-chair

intermediate

b/w half-chair and envelope

Figure 3. (a) Relative frequency of occurrence (in \%) for various types of conformations in six-membered rings A, B and C (molecules 1-45); (b) Relative frequency of occurrence (in $\%$ ) for various types of conformations in five-membered rings D (molecules 1-45)

\section{Structure activity relationship}

The biological activity spectra for substances are correlated on SAR base (Structure-activity relationships data and knowledge base), which provides different $\mathrm{P}_{\mathrm{a}}$ and $\mathrm{P}_{\mathrm{i}}$ values. Based on MNA(Multilevel Neighbourhood of atoms) descriptors for active and inactive compounds, 
the two probabilities have been calculated for each activity: $\mathrm{P}_{\mathrm{a}}$ - the probability of compound being active and $\mathrm{P}_{\mathrm{i}}$ - the probability of compound being inactive. The influence of these descriptors can be positive (if they are found in compounds with particular activity) or negative (if they are found in compounds without the particular activity) or neutral. The $\mathrm{P}_{\mathrm{a}}$ and $\mathrm{P}_{\mathrm{i}}$ values for the molecules (1-45) have been computed by the PASS software ${ }^{44}$ and are given in the Table 4.

Table 4. $\mathrm{Pa}$ and $\mathrm{P}_{\mathrm{i}}$ values for the molecules (1-45)

\begin{tabular}{|c|c|c|c|c|c|c|c|}
\hline $\begin{array}{l}\frac{0}{\bar{J}} \\
\frac{0}{0} \\
\sum\end{array}$ & 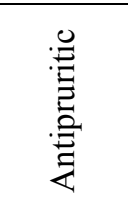 & 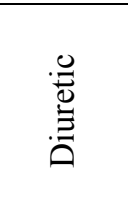 & 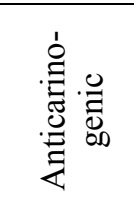 & 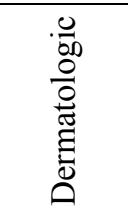 & 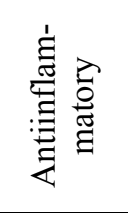 & 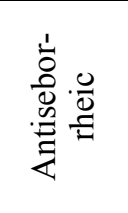 & 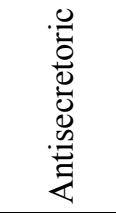 \\
\hline & $\mathrm{Pa}>\mathrm{Pi}$ & $\mathrm{Pa}>\mathrm{Pi}$ & $\mathrm{Pa}>\mathrm{Pi}$ & $\mathrm{Pa}>\mathrm{Pi}$ & $\mathrm{Pa}>\mathrm{Pi}$ & $\mathrm{Pa}>\mathrm{Pi}$ & $\mathrm{Pa}>\mathrm{Pi}$ \\
\hline M-1 & - & - & - & - & - & - & - \\
\hline M-2 & $\begin{array}{c}0.388> \\
0.016\end{array}$ & $\begin{array}{c}0.254> \\
0.141\end{array}$ & $\begin{array}{c}0.217> \\
0.103\end{array}$ & $\begin{array}{c}0.775> \\
0.005\end{array}$ & $\begin{array}{c}0.348> \\
0.029\end{array}$ & $\begin{array}{c}0.814> \\
0.016\end{array}$ & $\begin{array}{c}0.333> \\
0.079\end{array}$ \\
\hline M-3 & $\begin{array}{c}0.798> \\
0.004\end{array}$ & $\begin{array}{c}0.281> \\
0.103\end{array}$ & $\begin{array}{c}0.281> \\
0.067\end{array}$ & $\begin{array}{c}0.843> \\
0.004\end{array}$ & $\begin{array}{c}0.937> \\
0.004\end{array}$ & $\begin{array}{c}0.850> \\
0.010\end{array}$ & $\begin{array}{c}0.458> \\
0.039\end{array}$ \\
\hline M-4 & $\begin{array}{c}0.602> \\
0.016\end{array}$ & $\begin{array}{c}0.447> \\
0.008\end{array}$ & $\begin{array}{c}0.284> \\
0.065\end{array}$ & $\begin{array}{c}0.550> \\
0.022\end{array}$ & $\begin{array}{c}0.335> \\
0.039\end{array}$ & $\begin{array}{c}0.841> \\
0.012\end{array}$ & $\begin{array}{c}0.468> \\
0.037\end{array}$ \\
\hline M-5 & $\begin{array}{c}0.691> \\
0.009\end{array}$ & $\begin{array}{c}0.400> \\
0.021\end{array}$ & $\begin{array}{c}0.462> \\
0.023\end{array}$ & $\begin{array}{c}0.723> \\
0.006\end{array}$ & $\begin{array}{c}0.541> \\
0045\end{array}$ & $\begin{array}{c}0.893> \\
0.005\end{array}$ & $\begin{array}{c}0.729> \\
0.008\end{array}$ \\
\hline M-6 & $\begin{array}{c}0.732> \\
0.006\end{array}$ & $\begin{array}{c}0.361> \\
0.036\end{array}$ & $\begin{array}{c}0.443> \\
0.025\end{array}$ & $\begin{array}{c}0.650> \\
0.011\end{array}$ & $\begin{array}{c}0.404> \\
0.009\end{array}$ & $\begin{array}{c}0.889> \\
0.005\end{array}$ & $\begin{array}{c}0.672> \\
0.012\end{array}$ \\
\hline M-7 & $\begin{array}{c}0.580> \\
0.019\end{array}$ & $\begin{array}{c}0.355> \\
0.016\end{array}$ & $\begin{array}{c}0.345> \\
0.043\end{array}$ & $\begin{array}{c}0.627> \\
0.013\end{array}$ & $\begin{array}{c}0.499> \\
0.057\end{array}$ & $\begin{array}{c}0.780> \\
0.023\end{array}$ & $\begin{array}{c}0.529> \\
0.025\end{array}$ \\
\hline M-8 & $\begin{array}{c}0.670> \\
0.010\end{array}$ & $\begin{array}{c}0.239> \\
0.057\end{array}$ & $\begin{array}{c}0.245> \\
0.085\end{array}$ & $\begin{array}{c}0.520> \\
0.028\end{array}$ & $\begin{array}{c}0.308> \\
0.067\end{array}$ & $\begin{array}{c}0.349> \\
0.107\end{array}$ & $\begin{array}{c}0.199> \\
0.168\end{array}$ \\
\hline Mol 9 & $\begin{array}{c}0.661> \\
0.010\end{array}$ & $\begin{array}{c}0.259> \\
0.043\end{array}$ & $\begin{array}{c}0.210> \\
0.109\end{array}$ & $\begin{array}{c}0.843> \\
0.004\end{array}$ & $\begin{array}{c}0.786> \\
0.008\end{array}$ & $\begin{array}{c}0.887> \\
0.005\end{array}$ & $\begin{array}{c}0.546> \\
0.023\end{array}$ \\
\hline M-10 & $\begin{array}{c}0.689> \\
0.009\end{array}$ & $\begin{array}{c}0.305> \\
0.023\end{array}$ & $\begin{array}{c}0.430> \\
0.026\end{array}$ & $\begin{array}{c}0.640> \\
0.012\end{array}$ & $\begin{array}{c}0.429> \\
0.007\end{array}$ & $\begin{array}{c}0.862> \\
0.008\end{array}$ & $\begin{array}{c}0.520> \\
0.026\end{array}$ \\
\hline M-11 & $\begin{array}{c}0.762> \\
0.005\end{array}$ & $\begin{array}{c}0.236> \\
0.060\end{array}$ & $\begin{array}{c}0.312> \\
0.054\end{array}$ & $\begin{array}{c}0.936> \\
0.003\end{array}$ & $\begin{array}{c}0.057> \\
0.002\end{array}$ & $\begin{array}{c}0.932> \\
0.003\end{array}$ & $\begin{array}{c}0.526> \\
0.026\end{array}$ \\
\hline M-12 & $\begin{array}{c}0.698> \\
0.008\end{array}$ & $\begin{array}{c}0.223> \\
0.070\end{array}$ & $\begin{array}{c}0.231> \\
0.093\end{array}$ & $\begin{array}{c}0.735> \\
0.006\end{array}$ & $\begin{array}{c}0.525> \\
0.050\end{array}$ & $\begin{array}{c}0.787> \\
0.021\end{array}$ & $\begin{array}{c}0.440> \\
0.045\end{array}$ \\
\hline M-13 & $\begin{array}{c}0.529> \\
0.029\end{array}$ & - & $\begin{array}{c}0.207> \\
0.112\end{array}$ & $\begin{array}{c}0.737> \\
0.006\end{array}$ & $\begin{array}{c}0.257> \\
0.161\end{array}$ & $\begin{array}{c}0.497> \\
0.073\end{array}$ & $\begin{array}{c}0.253> \\
0.118\end{array}$ \\
\hline M-14 & $\begin{array}{c}0.651> \\
0.011\end{array}$ & $\begin{array}{c}0.189> \\
0.106\end{array}$ & $\begin{array}{c}0.224> \\
0.099\end{array}$ & $\begin{array}{c}0.878> \\
0.004\end{array}$ & $\begin{array}{c}0.780> \\
0.008\end{array}$ & $\begin{array}{c}0.737> \\
0.031\end{array}$ & $\begin{array}{c}0.603> \\
0.017\end{array}$ \\
\hline M-15 & $\begin{array}{c}0.878> \\
0.004\end{array}$ & $\begin{array}{c}0.189> \\
0.106\end{array}$ & $\begin{array}{c}0.224> \\
0.099\end{array}$ & $\begin{array}{c}0.878> \\
0.004\end{array}$ & $\begin{array}{c}0.307> \\
0.069\end{array}$ & $\begin{array}{c}0.737> \\
0.031\end{array}$ & $\begin{array}{c}0.603> \\
0.017\end{array}$ \\
\hline M-16 & $\begin{array}{c}0.642> \\
0.007\end{array}$ & $\begin{array}{c}0.526> \\
0.005\end{array}$ & $\begin{array}{c}0.218> \\
0.103\end{array}$ & $\begin{array}{c}0.773> \\
0.005\end{array}$ & $\begin{array}{c}0.060> \\
0.002\end{array}$ & $\begin{array}{c}0.896> \\
0.005\end{array}$ & $\begin{array}{c}0.769> \\
0.005\end{array}$ \\
\hline M-17 & $\begin{array}{c}0.642> \\
0.007\end{array}$ & $\begin{array}{c}0.526> \\
0.005\end{array}$ & $\begin{array}{c}0.218> \\
0.103\end{array}$ & $\begin{array}{c}0.773> \\
0.005\end{array}$ & $\begin{array}{c}0.060> \\
0.002\end{array}$ & $\begin{array}{c}0.896> \\
0.005\end{array}$ & $\begin{array}{c}0.769> \\
0.005\end{array}$ \\
\hline M-18 & - & - & - & - & - & - & - \\
\hline M-19 & - & - & - & - & - & - & - \\
\hline M-20 & $\begin{array}{c}0.755> \\
0.005\end{array}$ & $\begin{array}{c}0.469> \\
0.007\end{array}$ & $\begin{array}{c}0.568> \\
0.014\end{array}$ & $\begin{array}{c}0.701> \\
0.008\end{array}$ & $\begin{array}{c}0.384> \\
0.014\end{array}$ & $\begin{array}{c}0.904> \\
0.004\end{array}$ & $\begin{array}{c}0.641> \\
0.014\end{array}$ \\
\hline
\end{tabular}




\begin{tabular}{|c|c|c|c|c|c|c|c|}
\hline M-21 & $\begin{array}{c}0.755> \\
0.005\end{array}$ & $\begin{array}{c}0.469> \\
0.007\end{array}$ & $\begin{array}{c}0.568> \\
0.014\end{array}$ & $\begin{array}{c}0.701> \\
0.008\end{array}$ & $\begin{array}{c}0.384> \\
0.014\end{array}$ & $\begin{array}{c}0 . .904> \\
0.004\end{array}$ & $\begin{array}{c}0.641> \\
0.014\end{array}$ \\
\hline M-22 & $\begin{array}{c}0.431> \\
0.010\end{array}$ & $\begin{array}{c}0.452> \\
0.008\end{array}$ & $\begin{array}{c}0.222> \\
0.100\end{array}$ & $\begin{array}{c}0.812> \\
0.004\end{array}$ & $\begin{array}{c}0.392> \\
0.012\end{array}$ & $\begin{array}{c}0.881> \\
0.006\end{array}$ & $\begin{array}{c}0.467> \\
0.037\end{array}$ \\
\hline M-23 & $\begin{array}{c}0.599> \\
0.016\end{array}$ & $\begin{array}{c}0.509> \\
0.006\end{array}$ & - & $\begin{array}{c}0.584> \\
0.018\end{array}$ & $\begin{array}{c}0.613> \\
0.029\end{array}$ & $\begin{array}{c}0.351> \\
0.106\end{array}$ & $\begin{array}{c}0.228> \\
0.140\end{array}$ \\
\hline M-24 & $\begin{array}{c}0.751> \\
0.005\end{array}$ & $\begin{array}{c}0.290> \\
0.027\end{array}$ & $\begin{array}{c}0.351> \\
0.041\end{array}$ & $\begin{array}{c}0.629> \\
0.013\end{array}$ & $\begin{array}{c}0.405> \\
0.009\end{array}$ & $\begin{array}{c}0.480> \\
0.076\end{array}$ & $\begin{array}{c}0.449> \\
0.042\end{array}$ \\
\hline M-25 & $\begin{array}{c}0.696> \\
0.008\end{array}$ & $\begin{array}{c}0.346> \\
0.017\end{array}$ & $\begin{array}{c}0.220> \\
0.101\end{array}$ & $\begin{array}{c}0.552> \\
0.022\end{array}$ & $\begin{array}{c}0.300> \\
0.079\end{array}$ & $\begin{array}{c}0.742> \\
0.030\end{array}$ & - \\
\hline M-26 & $\begin{array}{c}0.796> \\
0.004\end{array}$ & - & $\begin{array}{c}0.423> \\
0.027\end{array}$ & $\begin{array}{c}0.747> \\
0.005\end{array}$ & $\begin{array}{c}0.769> \\
0.009\end{array}$ & $\begin{array}{c}0.866> \\
0.008\end{array}$ & $\begin{array}{c}0.374> \\
0.066\end{array}$ \\
\hline M-27 & $\begin{array}{c}0.595> \\
0.016\end{array}$ & $\begin{array}{c}0.268> \\
0.037\end{array}$ & $\begin{array}{c}0.330> \\
0.048\end{array}$ & $\begin{array}{c}0.627> \\
0.013\end{array}$ & $\begin{array}{c}0.397> \\
0.097\end{array}$ & $\begin{array}{c}0.792> \\
0.021\end{array}$ & $\begin{array}{c}0.216> \\
0.152\end{array}$ \\
\hline M-28 & - & - & - & - & - & - & - \\
\hline M-29 & $\begin{array}{c}0.691> \\
0.009\end{array}$ & $\begin{array}{c}0.331> \\
0.019\end{array}$ & $\begin{array}{c}0.211> \\
0.109\end{array}$ & $\begin{array}{c}0.891> \\
0.004\end{array}$ & $\begin{array}{c}0.545> \\
0.044\end{array}$ & $\begin{array}{c}0.871> \\
0.007\end{array}$ & $\begin{array}{c}0.559> \\
0.022\end{array}$ \\
\hline M-30 & $\begin{array}{c}0.601> \\
0.016\end{array}$ & $\begin{array}{c}0.325> \\
0.020\end{array}$ & - & $\begin{array}{c}0.679> \\
0.009\end{array}$ & $\begin{array}{c}0.236> \\
0.230\end{array}$ & $\begin{array}{c}0.809> \\
0.017\end{array}$ & $\begin{array}{c}0.329> \\
0.080\end{array}$ \\
\hline M-31 & $\begin{array}{c}0.787> \\
0.004\end{array}$ & $\begin{array}{c}0.173> \\
0.129\end{array}$ & $\begin{array}{c}0.295> \\
0.060\end{array}$ & $\begin{array}{c}0.750> \\
0.005\end{array}$ & $\begin{array}{c}0.625> \\
0.027\end{array}$ & $\begin{array}{c}0.621> \\
0.051\end{array}$ & $\begin{array}{c}0.560> \\
0.022\end{array}$ \\
\hline M-32 & $\begin{array}{c}0.702> \\
0.008\end{array}$ & $\begin{array}{c}0.382> \\
0.013\end{array}$ & $\begin{array}{c}0.222> \\
0.099\end{array}$ & $\begin{array}{c}0.765> \\
0.005\end{array}$ & $\begin{array}{c}0.377> \\
0.108\end{array}$ & $\begin{array}{c}0.884> \\
0.005\end{array}$ & $\begin{array}{c}0.543> \\
0.023\end{array}$ \\
\hline M-33 & $\begin{array}{c}0.506> \\
0.033\end{array}$ & $\begin{array}{c}0.353> \\
0.016\end{array}$ & $\begin{array}{c}0.276> \\
0.069\end{array}$ & $\begin{array}{c}0.577> \\
0.019\end{array}$ & $\begin{array}{c}0.373> \\
0.017\end{array}$ & $\begin{array}{c}0.674> \\
0.042\end{array}$ & $\begin{array}{c}0.438> \\
0.046\end{array}$ \\
\hline M-34 & $\begin{array}{c}0.599> \\
0.016\end{array}$ & $\begin{array}{c}0.540> \\
0.005\end{array}$ & - & $\begin{array}{c}0.812> \\
0.004\end{array}$ & $\begin{array}{c}0.333> \\
0.041\end{array}$ & $\begin{array}{c}0.634> \\
0.049\end{array}$ & $\begin{array}{c}0.528> \\
0.025\end{array}$ \\
\hline M-35 & $\begin{array}{c}0.693> \\
0.008\end{array}$ & $\begin{array}{c}0.281> \\
0.031\end{array}$ & $\begin{array}{c}0.366> \\
0.037\end{array}$ & $\begin{array}{c}0.602> \\
0.015\end{array}$ & $\begin{array}{c}0.430> \\
0.081\end{array}$ & $\begin{array}{c}0.820> \\
0.015\end{array}$ & $\begin{array}{c}0.356> \\
0.071\end{array}$ \\
\hline M-36 & $\begin{array}{c}0.695> \\
0.008\end{array}$ & $\begin{array}{c}0.406> \\
0.011\end{array}$ & $\begin{array}{c}0.237> \\
0.090\end{array}$ & $\begin{array}{c}0.663> \\
0.010\end{array}$ & $\begin{array}{c}0.491> \\
0.060\end{array}$ & $\begin{array}{c}0.840> \\
0.012\end{array}$ & $\begin{array}{c}0.339> \\
0.077\end{array}$ \\
\hline M-37 & $\begin{array}{c}0.707> \\
0.008\end{array}$ & $\begin{array}{c}0.330> \\
0.019\end{array}$ & $\begin{array}{c}0.277> \\
0.068\end{array}$ & $\begin{array}{c}0.754> \\
0.005\end{array}$ & $\begin{array}{c}0.484> \\
0.062\end{array}$ & $\begin{array}{c}0.880> \\
0.006\end{array}$ & $\begin{array}{c}0.344> \\
0.075\end{array}$ \\
\hline M-38 & $\begin{array}{c}0.645> \\
0.012\end{array}$ & $\begin{array}{c}0.336> \\
0.018\end{array}$ & $\begin{array}{c}0.315> \\
0.053\end{array}$ & $\begin{array}{c}0.537> \\
0.025\end{array}$ & $\begin{array}{c}0.453> \\
0.072\end{array}$ & $\begin{array}{c}0.759> \\
0.027\end{array}$ & $\begin{array}{c}0.343> \\
0.076\end{array}$ \\
\hline M-39 & $\begin{array}{c}0.558> \\
0.023\end{array}$ & - & $\begin{array}{c}0.198> \\
0.122\end{array}$ & $\begin{array}{c}0.610> \\
0.014\end{array}$ & $\begin{array}{c}0.349> \\
0.029\end{array}$ & $\begin{array}{c}0.820> \\
0.015\end{array}$ & $\begin{array}{c}0.473> \\
0.035\end{array}$ \\
\hline M-40 & $\begin{array}{c}0.518> \\
0.031\end{array}$ & $\begin{array}{c}0.253> \\
0.047\end{array}$ & $\begin{array}{c}0.363> \\
0.038\end{array}$ & $\begin{array}{c}0.580> \\
0.018\end{array}$ & $\begin{array}{c}0.322> \\
0.051\end{array}$ & $\begin{array}{c}0.768> \\
0.025\end{array}$ & $\begin{array}{c}0.221> \\
0.148\end{array}$ \\
\hline M-41 & $\begin{array}{c}0.552> \\
0.024\end{array}$ & $\begin{array}{c}0.303> \\
0.024\end{array}$ & $\begin{array}{c}0.372> \\
0.036\end{array}$ & $\begin{array}{c}0.617> \\
0.014\end{array}$ & $\begin{array}{c}0.461> \\
0.069\end{array}$ & $\begin{array}{c}0.868> \\
0.007\end{array}$ & $\begin{array}{c}0.454> \\
0.041\end{array}$ \\
\hline M-42 & $\begin{array}{c}0.687> \\
0.009\end{array}$ & $\begin{array}{c}0.576> \\
0.005\end{array}$ & $\begin{array}{c}0.372> \\
0.036\end{array}$ & $\begin{array}{c}0.770> \\
0.005\end{array}$ & $\begin{array}{c}0.366> \\
0.113\end{array}$ & $\begin{array}{c}0.931> \\
0.003\end{array}$ & $\begin{array}{c}0.650> \\
0.014\end{array}$ \\
\hline M-43 & $\begin{array}{c}0.600> \\
0.016\end{array}$ & $\begin{array}{c}0.262> \\
0.040\end{array}$ & $\begin{array}{c}0.175> \\
0.152\end{array}$ & $\begin{array}{c}0.797> \\
0.004\end{array}$ & $\begin{array}{c}0.471> \\
0.066\end{array}$ & $\begin{array}{c}0.475> \\
0.077\end{array}$ & $\begin{array}{c}0.758> \\
0.005\end{array}$ \\
\hline M-44 & $\begin{array}{c}0.640> \\
0.012\end{array}$ & $\begin{array}{c}0.258> \\
0.044\end{array}$ & - & $\begin{array}{c}0.778> \\
0.005\end{array}$ & $\begin{array}{c}0.408> \\
0.091\end{array}$ & $\begin{array}{c}0.576> \\
0.059\end{array}$ & $\begin{array}{c}0.654> \\
0.013\end{array}$ \\
\hline M-45 & $\begin{array}{c}0.671> \\
0.010\end{array}$ & $\begin{array}{c}0.618> \\
0.004\end{array}$ & $\begin{array}{c}0.191> \\
0.130\end{array}$ & $\begin{array}{c}0.703> \\
0.008\end{array}$ & $\begin{array}{c}0.522 \\
>0.050\end{array}$ & $\begin{array}{c}0.836> \\
0.012\end{array}$ & $\begin{array}{c}0.775> \\
0.005\end{array}$ \\
\hline
\end{tabular}


A majority of the androstane derivatives appear to possess high antiprurtic and antiseborrheic activity while anti-inflammatory activity is not that significant. The diuretic and anticarcinogenic activity in most of the androstane derivatives is found to be significantly low while the dermatological activity is predominantly high.

\section{Hydrogen bonding}

Hydrogen bonds have been known since the beginning of this century, but were brought into the common body of knowledge by Pauling in 1939, in his book The Nature of the Chemical Bond $^{45}$. Strong and weak hydrogen bonds are discussed by Jeffrey and Saenger, in Hydrogen Bonding in Biological Structures ${ }^{46.47}$.

Based on the comparative data of intra- and intermolecular interactions of the types $\mathrm{C}$ $\mathrm{H} . . \mathrm{O}, \mathrm{O}-\mathrm{H} . . . \mathrm{O}$ and $\mathrm{C}-\mathrm{H} . . . \mathrm{Br}$ as observed in the steroidal molecules (1-45) and presented in Table 5, it has been observed that the $\mathrm{O}$ atom is the predominant hydrogen donor and acceptor. The overall $\mathrm{d}(\mathrm{H} . . . \mathrm{A})$ range lies between 1.94 and $2.13 \AA$, the $\mathrm{D}(\mathrm{X} . . \mathrm{A})$ range is between 2.71 and $2.86 \AA$, and the angular range $\Theta(\mathrm{X}-\mathrm{H} . . . \mathrm{A})$ falls between 156 and $169^{\circ}$. Table 5 presents a range of values for $\mathrm{d}, \mathrm{D}$ and $\Theta$ as exist in case of C-H...O and O-H...O intramolecular interactions.

Table 5. Geometry of $\mathrm{C}-\mathrm{H} \ldots \mathrm{O}, \mathrm{O}-\mathrm{H} . . \mathrm{O}$ and $\mathrm{C}-\mathrm{H} \ldots \mathrm{Br} / \mathrm{C}-\mathrm{H} . . . \mathrm{Cl} / \mathrm{C}-\mathrm{H} \ldots \mathrm{F}$ intra- and intermolecular interactions

\begin{tabular}{|c|c|c|c|c|}
\hline $\begin{array}{l}\text { Molecule [Number of } \\
\text { Donors and Acceptors] }\end{array}$ & $\begin{array}{c}\text { Intramolecular } \\
\text { interaction }(\mathrm{X}-\mathrm{H} . . . \mathrm{A})\end{array}$ & $\begin{array}{c}\mathrm{H} \ldots \mathrm{A}(\AA) \\
\mathrm{d}\end{array}$ & $\begin{array}{c}\mathrm{X} \ldots \mathrm{A}(\AA) \\
\mathrm{D} \\
\end{array}$ & $\begin{array}{c}\mathrm{X}-\mathrm{H} \ldots \mathrm{A}\left({ }^{\circ}\right) \\
\Theta \\
\end{array}$ \\
\hline $\begin{array}{c}\text { M-26 } \\
\text { XEYTOL } \\
\text { Donors }=1 \\
\text { Acceptors }=1\end{array}$ & O3-H3X...O1 & 2.13 & 2.841 & 156 \\
\hline $\begin{array}{c}\text { M-42 } \\
\text { EVARUP } \\
\text { Donors }=3 \\
\text { Acceptors }=3\end{array}$ & $\begin{array}{c}\text { O5-H5 ...OW1 } \\
\text { O17-H17...OW3 } \\
\text { OW2-HW21...O17 }\end{array}$ & $\begin{array}{l}1.98 \\
1.94 \\
2.05\end{array}$ & $\begin{array}{l}2.78 \\
2.71 \\
2.86\end{array}$ & $\begin{array}{l}169 \\
159 \\
168\end{array}$ \\
\hline & $\begin{array}{l}\text { Intermolecular } \\
\text { interactions }\end{array}$ & & & \\
\hline $\begin{array}{c}\text { M-1 } \\
\text { Donors }=3 \\
\text { Acceptors }=3\end{array}$ & $\begin{array}{c}\mathrm{C} 2-\mathrm{H} 2 \mathrm{~B} \ldots \mathrm{O} 4 \\
\mathrm{C} 5-\mathrm{H} 5 \ldots . . \mathrm{O} 17 \\
\mathrm{C} 5-\mathrm{H} 5 \ldots \mathrm{O} 20 \\
\mathrm{C} 21-\mathrm{H} 21 \mathrm{~A} . . . \mathrm{O} 17\end{array}$ & $\begin{array}{l}2.662 \\
2.534 \\
2.692 \\
2.376\end{array}$ & $\begin{array}{l}3.384 \\
3.155 \\
3.634 \\
3.340\end{array}$ & $\begin{array}{l}128.16 \\
120.01 \\
157.14 \\
167.66\end{array}$ \\
\hline $\begin{array}{c}\mathrm{M}-2 \\
\text { Donors }=3 \\
\text { Acceptors }=2\end{array}$ & $\begin{array}{c}\text { C4-H4...O3 } \\
\text { C7-H7A...O3 } \\
\text { C17B-H17B...O1 }\end{array}$ & $\begin{array}{l}2.714 \\
2.592 \\
2.600\end{array}$ & $\begin{array}{l}3.688 \\
3.524 \\
3.517\end{array}$ & $\begin{array}{l}171.71 \\
160.99 \\
169.99\end{array}$ \\
\hline $\begin{array}{c}\text { M-3 } \\
\text { Donors }=3 \\
\text { Acceptors }=2\end{array}$ & $\begin{array}{c}\text { C1-H1A...O3 } \\
\text { O3-H3A...O17 } \\
\text { O11-H11A...O3 }\end{array}$ & $\begin{array}{c}2.666 \\
2.08 \\
2.05\end{array}$ & $\begin{array}{l}3.625 \\
2.874 \\
2.862\end{array}$ & $\begin{array}{c}169.80 \\
164 \\
171\end{array}$ \\
\hline $\begin{array}{c}\text { M-4 } \\
\text { Donors }=4 \\
\text { Acceptors }=3\end{array}$ & $\begin{array}{c}\text { C6-H6A...O1 } \\
\text { C11-H11A...O4 } \\
\text { C20-H20B...O4 } \\
\text { O3-H3...O2 }\end{array}$ & $\begin{array}{l}2.362 \\
2.432 \\
2.588 \\
2.101\end{array}$ & $\begin{array}{l}3.311 \\
3.257 \\
3.412 \\
2.787\end{array}$ & $\begin{array}{l}165.86 \\
142.59 \\
144.72 \\
141.01\end{array}$ \\
\hline
\end{tabular}




\begin{tabular}{|c|c|c|c|c|}
\hline \multirow{6}{*}{$\begin{array}{c}\text { M-5 } \\
\text { Donors }=5 \\
\text { Acceptors }=4\end{array}$} & O1-H1...O2 & 1.878 & 2.672 & 157.13 \\
\hline & $\mathrm{O} 4(\mathrm{~W})-\mathrm{H} 4 \mathrm{C} \ldots \mathrm{O} 1$ & 1.953 & 2.849 & 161.60 \\
\hline & $\mathrm{O} 2-\mathrm{H} 2 \ldots \mathrm{O} 3$ & 1.932 & 2.744 & 162.18 \\
\hline & $\mathrm{O} 3-\mathrm{H} 3 \ldots \mathrm{O} 4(\mathrm{~W})$ & 1.910 & 2.686 & 153.06 \\
\hline & O4-H4D...O1 & 2.102 & 2.869 & 167.73 \\
\hline & C18-H18B...O4(W) & 2.715 & 3.311 & 119.61 \\
\hline M-6 & C16-H16A...O4 & 2.707 & 3.462 & 135.11 \\
\hline Donors $=3$ & O3-H3...O17 & 2.035 & 2.792 & 149.20 \\
\hline Acceptors $=3$ & $\mathrm{O} 4-\mathrm{H} 4 \ldots \mathrm{O} 3$ & 1.93 & 2.751 & 168 \\
\hline M-7 & C15-H15A...O4 & 2.573 & 3.474 & 153.45 \\
\hline Donors $=2$ & C15-H15B...O1 & 2.458 & 3.397 & 162.93 \\
\hline Acceptors $=3$ & C21-H21A...O5 & 2.504 & 3.362 & 152.02 \\
\hline \multirow{4}{*}{$\begin{array}{c}\text { M-8 } \\
\text { Donors }=4 \\
\text { Acceptors }=3\end{array}$} & C6-H6...O3B & 2.651 & 3.413 & 134.78 \\
\hline & C15-H15A...O17 & 2.66 & 3.609 & 163.70 \\
\hline & C18-H18A...O7 & 2.630 & 3.419 & 134.64 \\
\hline & O7-H7A...O17 & 2.023 & 2.825 & 165.69 \\
\hline \multirow{2}{*}{$\begin{array}{c}\text { M-9 } \\
\text { Donors }=2 \\
\text { Acceptors }=2\end{array}$} & $\mathrm{C} 24-\mathrm{H} 24 \mathrm{C}$ & 2.690 & 3.459 & 134.80 \\
\hline & C15-H15A...O4 & 2.639 & 3.590 & 160.98 \\
\hline \multirow{7}{*}{$\begin{array}{c}\text { M-10 } \\
\text { Donors }=5 \\
\text { Acceptors }=4\end{array}$} & C11-H11B...O20 & 2.713 & 3.683 & 177.96 \\
\hline & C19-H19A...O20 & 2.502 & 3.366 & 149.72 \\
\hline & C19-H19C...O5' & 2.696 & 3.382 & 128.88 \\
\hline & C19'-H19F...O5 & 2.543 & 3.361 & 143.21 \\
\hline & C8'-H8'...O20' & 2.648 & 3.403 & 134 \\
\hline & C2'-H2'2...O17 & 2.702 & 3.652 & 166.75 \\
\hline & O5-H5...O5' & 2.101 & 2.983 & 165.51 \\
\hline \multirow{4}{*}{$\begin{array}{c}\text { M-11 } \\
\text { Donors }=4 \\
\text { Acceptors }=2\end{array}$} & C2-H2A...O3 & 2.562 & 3.319 & 135.01 \\
\hline & C4-H4C...O3 & 2.699 & 3.415 & 131.10 \\
\hline & С19-H19B...O3 & 2.627 & 3.568 & 178.19 \\
\hline & $\mathrm{O} 3-\mathrm{H} 3(\mathrm{O} 3) \ldots \mathrm{O} 2$ & 1.994 & 2.813 & 177.65 \\
\hline \multirow{4}{*}{$\begin{array}{c}\text { M- } 12 \\
\text { Donors }=4 \\
\text { Acceptors }=2\end{array}$} & $\mathrm{C} 22^{\prime}-\mathrm{H} 2$ 'B...O3 & 2.613 & 3.422 & 140.07 \\
\hline & O3'-H3'(O3')...O3 & 2.137 & 2.920 & 157.13 \\
\hline & C1-H1B...O17' & 2.413 & 3.375 & 166.72 \\
\hline & C24-H24...O17' & 2.494 & 3.368 & 154.52 \\
\hline \multirow{2}{*}{$\begin{array}{c}\text { M- 13 } \\
\text { Donors }=2 \\
\text { Acceptors }=2\end{array}$} & С9-H9...O3 & 2.596 & 3.56 & 167.05 \\
\hline & C23-H23C...O2 & 2.516 & 3.297 & 138.42 \\
\hline \multirow{4}{*}{$\begin{array}{c}\mathrm{M}-14 \\
\text { Donors }=3 \\
\text { Acceptors }=3\end{array}$} & C16-H16А...O20 & 2.677 & 3.418 & 133.54 \\
\hline & C21-H21C...O20 & 2.688 & 3.628 & 166.38 \\
\hline & С23-H23А...O17 & 2.519 & 3.322 & 141.27 \\
\hline & C23-H23B...O22 & 2.501 & 3.303 & 141.01 \\
\hline \multirow{5}{*}{$\begin{array}{c}\text { M-15 } \\
\text { Donors }=4 \\
\text { Acceptors }=4\end{array}$} & C2-H2B...O20 & 2.701 & 3.604 & 154.99 \\
\hline & C2-H2A...O22 & 2.615 & 3.567 & 167.28 \\
\hline & С9-H9...О20 & 2.465 & 3.418 & 164.36 \\
\hline & C18-H18C...O17 & 2.640 & 3.590 & 170.21 \\
\hline & C21-H21B...O3 & 2.453 & 3.395 & 167.17 \\
\hline
\end{tabular}




\begin{tabular}{|c|c|c|c|c|}
\hline & C12-H12B...O3 & 2.611 & 3.473 & 146.74 \\
\hline M- 16 & C19-H19C...O2 & 2.655 & 3.465 & 140.32 \\
\hline Donors $=5$ & O1-H1X...O3 & 1.952 & 2.808 & 163.30 \\
\hline \multirow[t]{2}{*}{ Acceptors $=4$} & O2-H4Y...O4 & 2.028 & 2.777 & 162.44 \\
\hline & O4-H4X...O1 & 1.678 & 2.766 & 171.97 \\
\hline & O3-H3X...O1 & 2.038 & 2.903 & 167.84 \\
\hline & O3'-H3Y...O3 & 1.879 & 2.868 & 170.81 \\
\hline M-17 & C19-H19B...O2' & 2.438 & 3.345 & 153.72 \\
\hline Donors $=4$ & $\mathrm{C} 1$ '-H1B2...O2 & 2.624 & 3.508 & 147.93 \\
\hline \multirow[t]{4}{*}{ Acceptors $=3$} & $\mathrm{O} 1{ }^{\prime}-\mathrm{H} 1 \mathrm{Y} . . . \mathrm{O} 2$ & 1.929 & 2.822 & 151.49 \\
\hline & C1-H1B...OI' & 2.522 & 3.465 & 159.25 \\
\hline & O1-H1X...O1' & 2.233 & 3.318 & 177.68 \\
\hline & C6'-H6' 1...O3' & 2.630 & 3.504 & 147.19 \\
\hline & C4-H4...O2 & 2.635 & 3.444 & 137.97 \\
\hline M-18 & C22-H22E...O3 & 2.696 & 3.414 & 141.02 \\
\hline Donors $=3$ & $\mathrm{C} 22-\mathrm{H} 22 \mathrm{C} . . . \mathrm{O} 3$ & 2.692 & 3.414 & 130.85 \\
\hline \multirow[t]{2}{*}{ Acceptors $=2$} & C22-H22D...O2 & 2.698 & 3.656 & 165.87 \\
\hline & $\mathrm{O} 3-\mathrm{H} 3 \mathrm{X} \ldots \mathrm{O} 2$ & 2.079 & 2.899 & 167.35 \\
\hline M-19 & & & & \\
\hline Donors $=1$ & O3-H3X...O4 & 2.062 & 2.976 & 171.13 \\
\hline Acceptors $=1$ & & & & \\
\hline \multirow{9}{*}{$\begin{array}{c}\text { M-20 } \\
\text { Donors }=4 \\
\text { Acceptors }=3\end{array}$} & C16'-H16'B...O1 & 2.509 & 3.435 & 154.93 \\
\hline & $\mathrm{O} 1-\mathrm{H} 1 \ldots \mathrm{O} 3(\mathrm{~W})$ & 1.955 & 2.831 & 169.47 \\
\hline & C16-H16A...O3(W) & 2.542 & 3.470 & 167.74 \\
\hline & C15-H15B...O1 & 2.591 & 3.375 & 136.10 \\
\hline & $\mathrm{O} 1$ '-H1O1'...O & 1.938 & 2.756 & 178.94 \\
\hline & C2'-H2'A...O2 & 2.576 & 3.335 & 132.64 \\
\hline & $\mathrm{O} 3(\mathrm{~W})-\mathrm{H} 2 \mathrm{O} 3 \ldots \mathrm{O} 2{ }^{\prime}$ & 1.707 & 2.747 & 157.96 \\
\hline & $\mathrm{O} 3(\mathrm{~W})-\mathrm{H} 1 \mathrm{O} 3 \ldots \mathrm{O} 1^{\prime}$ & 1.655 & 2.799 & 168.88 \\
\hline & C2'-H2'A...O2 & 2.576 & 3.335 & 132.84 \\
\hline M- 21 & C15-H15A...O1 & 2.536 & 3.347 & 142.55 \\
\hline Donors $=3$ & C16-H16B...O2 & 2.653 & 3.424 & 136.89 \\
\hline Acceptors $=2$ & $\mathrm{O} 1-\mathrm{H} 1 \ldots \mathrm{O} 2$ & 2.130 & 2.956 & 175.43 \\
\hline \multirow{4}{*}{$\begin{array}{c}\text { M-22 } \\
\text { Donors }=4 \\
\text { Acceptors }=3\end{array}$} & C1-H1A...O4 & 2.709 & 3.52 & 134.36 \\
\hline & C15-H15B...O3 & 2.719 & 3.212 & 111.09 \\
\hline & C19-H19A...O3 & 2.583 & 3.518 & 159.48 \\
\hline & $\mathrm{O} 4-\mathrm{H} 4 \ldots \mathrm{O} 1$ & 1.944 & 2.754 & 161.71 \\
\hline & C1-H1A...O3 & 2.590 & 3.479 & 152.58 \\
\hline M-23 & C11-H11A...O3 & 2.704 & 3.670 & 174.04 \\
\hline Donors $=4$ & C18-H18A...O4 & 2.614 & 3.518 & 157.26 \\
\hline \multirow[t]{2}{*}{ Acceptors $=2$} & C20-H20A...O4 & 2.631 & 3.451 & 142.39 \\
\hline & C20-H20B...O4 & 2.717 & 3.362 & 124.46 \\
\hline M- 24 & C3B-H3B1...O5 & 2.611 & 3.387 & 138.07 \\
\hline Donors $=3$ & C18-H18A...O17 & 2.695 & 3.397 & 164.07 \\
\hline Acceptors $=2$ & O6-H6A...O17 & 2.025 & 2.822 & 130.49 \\
\hline M-25 & C8-H8...O4 & 2.475 & 3.352 & 148.75 \\
\hline Donors $=3$ & C11-H11A...O2 & 2.681 & 3.611 & 160.70 \\
\hline Acceptors $=3$ & $\mathrm{C} 21-\mathrm{H} 21 \mathrm{~B} \ldots \mathrm{O} 3$ & 2.715 & 3.554 & 146.29 \\
\hline
\end{tabular}




\begin{tabular}{|c|c|c|c|c|}
\hline \multirow{7}{*}{$\begin{array}{c}\text { M-26 } \\
\text { Donors }=6 \\
\text { Acceptors }=3\end{array}$} & O3-H3X...O4 & 1.98 & & 155 \\
\hline & O7-H7X...O8 & 2.03 & 2.745 & 160 \\
\hline & C18'-H48A...O3 & 2.690 & $\begin{array}{l}2.791 \\
2.257\end{array}$ & 127.14 \\
\hline & C16'-H46A...O4 & 2.602 & & 158.74 \\
\hline & C6'-H36...O8 & 2.635 & & 116.42 \\
\hline & O7-H7X...O8 & 2.03 & & 160 \\
\hline & C19-H19A...O4 & 2.698 & 3.194 & 130.11 \\
\hline \multirow{4}{*}{$\begin{array}{c}\text { M-27 } \\
\text { Donors }=2 \\
\text { Acceptors }=3\end{array}$} & C21-H2A...O4 & 2.523 & 3.477 & 164.22 \\
\hline & C23-H17B...O6 & 2.512 & 3.367 & 148.51 \\
\hline & C23-H7C...O2 & 2.509 & 3.326 & 140.70 \\
\hline & $\mathrm{O} 5-\mathrm{H} 23 \ldots \mathrm{O} 6$ & 1.966 & 2.884 & 155.67 \\
\hline \multirow{2}{*}{$\begin{array}{c}\text { M-28 } \\
\text { Donors }=2 \\
\text { Acceptors }=2\end{array}$} & C4-H5 ...O2 & 2.483 & 3.450 & 169.79 \\
\hline & $\mathrm{O} 2-\mathrm{H} 32 \ldots \mathrm{O} 1$ & 1.979 & 2.922 & 177.04 \\
\hline \multirow{2}{*}{$\begin{array}{c}\text { M-29 } \\
\text { Donors }=1 \\
\text { Acceptors }=1\end{array}$} & & & & \\
\hline & C15-H15B...O17B & 2.704 & 3.406 & 129.52 \\
\hline \multirow{4}{*}{$\begin{array}{c}\text { M- } 30 \\
\text { Donors }=4 \\
\text { Acceptors }=3\end{array}$} & C3-H9...O3B & 2.714 & 3.621 & 153.98 \\
\hline & C6B-H6B3...O14 & 2.452 & 3.375 & 161.00 \\
\hline & C15-H15B...O17B & 2.712 & 3.408 & 129.15 \\
\hline & O14-H14...O3B & 2.324 & 2.980 & 137.36 \\
\hline \multirow{4}{*}{$\begin{array}{c}M-31 \\
\text { Donors }=4 \\
\text { Acceptors }=3\end{array}$} & C16-H161...O3 & 2.696 & 3.444 & 132.57 \\
\hline & $\mathrm{C} 15-\mathrm{H} 151 \ldots \mathrm{O} 2$ & 2.389 & 3.153 & 133.44 \\
\hline & C2-H212...O3 & 2.620 & 3.546 & 157.59 \\
\hline & $\mathrm{C} 1-\mathrm{H} 11 \ldots \mathrm{F} 1$ & 2.437 & 3.373 & 157.43 \\
\hline M-32 & C1-H1B...O12 & 2.571 & 3.438 & 148.86 \\
\hline Donors $=3$ & C3-H3...O12 & 2.677 & 3.529 & 145.53 \\
\hline Acceptors $=2$ & C15-H15B...O17B & 2.6739 & 3.424 & 133.95 \\
\hline M-33 & C11-H11A...O1 & 2.699 & 3.387 & 128.32 \\
\hline Donors $=3$ & C16-H16A...O2 & 2.588 & 3.436 & 146.35 \\
\hline Acceptors $=2$ & C20-H20C...O2 & 2.669 & 3.584 & 159.63 \\
\hline \multirow{3}{*}{$\begin{array}{c}\text { M-34 } \\
\text { Donors }=1 \\
\text { Acceptors }=1\end{array}$} & & & & \\
\hline & C24-H24C...O1 & 2.638 & 3.567 & 163.43 \\
\hline & & & & \\
\hline \multirow{10}{*}{$\begin{array}{c}\text { M-35 } \\
\text { Donors }=6 \\
\text { Acceptors }=2\end{array}$} & O3-H30...O4 & 2.113 & 2.842 & 144.92 \\
\hline & C6-H6...O4 & 2.495 & 3.114 & 119.63 \\
\hline & C12'-H12C...O2 & 2.704 & 3.544 & 142.85 \\
\hline & C11-H11B...O2' & 2.682 & 3.415 & 131.02 \\
\hline & C16-H16А...O4' & 2.627 & 3.586 & 163.32 \\
\hline & C21'-H21E...O2 & 2.716 & 3.350 & 122.06 \\
\hline & O3'-H30'...O4' & 1.940 & 2.737 & 157.97 \\
\hline & C6'-H6'...O4' & 2.638 & 3.174 & 113.66 \\
\hline & C18-H18C...O3' & 2.529 & 3.361 & 142.55 \\
\hline & C16'-H16C...O3 & 2.611 & 3.424 & 139.39 \\
\hline M- 36 & C11-H11A...O5 & 2.599 & 3.508 & 152.62 \\
\hline Donors $=3$ & O1-H1_..O5 & 2.166 & 2.984 & 164.35 \\
\hline Acceptors $=1$ & O3-H3A...O5 & 2.198 & 2.980 & 154.88 \\
\hline
\end{tabular}




\begin{tabular}{|c|c|c|c|c|}
\hline & C7-H7B...O1 & 2.464 & 3.418 & 161.79 \\
\hline M- 37 & O1-H1X...O5 & 2.152 & 2.984 & 171.11 \\
\hline Donors $=5$ & O2-H2X...O6(W) & 1.979 & 2.776 & 157.99 \\
\hline \multirow[t]{2}{*}{ Acceptors $=3$} & O3-H3X...O1 & 2.134 & 2.912 & 153.82 \\
\hline & O6(W)-H6Y...O5 & 1.883 & 2.861 & 168.30 \\
\hline M-38 & C18-H18B...O5 & 2.695 & 3.449 & 134.08 \\
\hline Donors $=3$ & C21-H21C...O2 & 2.500 & 3.376 & 148.64 \\
\hline Acceptors $=2$ & O4-H4X...O5 & 2.005 & 2.792 & 156.53 \\
\hline \multirow{6}{*}{$\begin{array}{c}\text { M-39 } \\
\text { Donors }=5 \\
\text { Acceptors }=3\end{array}$} & O3-H3A...O3' & 2.12 & 2.936 & 179 \\
\hline & O6-H6...O2' & 1.97 & 2.757 & 160 \\
\hline & C16-H16...O3' & 2.56 & 3.347 & 137 \\
\hline & C2'-H22A...Br1 & 2.92 & 3.868 & 166 \\
\hline & C16'-H37...Br1 & 2.87 & 3.788 & 156 \\
\hline & C1'-H22A...Br1 & 2.919 & 2.919 & 166.16 \\
\hline M-40 & O3-H3...O17 & 2.112 & 2.931 & 174.88 \\
\hline Donors $=3$ & O5-H5...O3 & 1.995 & 2.806 & 170.43 \\
\hline Acceptors $=3$ & O6-H6A...O5 & 2.393 & 3.120 & 148.23 \\
\hline \multirow{9}{*}{$\begin{array}{c}\text { M-41 } \\
\text { Donors }=7 \\
\text { Acceptors }=6\end{array}$} & C9-H9...O6 & 2.511 & 3.469 & 165.76 \\
\hline & O3-H3...O17 & 1.979 & 2.788 & 168.59 \\
\hline & O5-H5...O(W1) & 2.080 & 2.891 & 170.32 \\
\hline & O6-H6...O5 & 2.260 & 2.26 & 149 \\
\hline & O17-H17...O(W3) & 1.94 & 2.718 & 159 \\
\hline & OW1-HW11...O3 & 2.152 & 2.944 & 170 \\
\hline & OW2-HW21...O17 & 2.05 & 2.862 & 168 \\
\hline & OW3-HW31...OW1 & 2.05 & 2.850 & 169 \\
\hline & OW1-HW12...OW2 & 2.19 & 2.977 & 160 \\
\hline \multirow{4}{*}{$\begin{array}{c}\text { M-42 } \\
\text { Donors }=4 \\
\text { Acceptors }=2\end{array}$} & C4-H4B...O2 & 2.699 & 3.543 & 145.77 \\
\hline & C7-H8B...O1 & 2.706 & 3.414 & 130.25 \\
\hline & С19-H9С...O1 & 2.683 & 3.529 & 147.37 \\
\hline & C9-H10...O2 & 2.632 & 3.589 & 165.43 \\
\hline \multirow{3}{*}{$\begin{array}{c}\mathrm{M}-43 \\
\text { Donors }=2 \\
\text { Acceptors }=2\end{array}$} & $\mathrm{C} 1-\mathrm{H} 1 \ldots \mathrm{O} 2$ & 2.611 & 3.355 & 131.90 \\
\hline & C21-H27...O2 & 2.713 & 3.492 & 136.76 \\
\hline & C21-H28...O1 & 2.689 & 3.506 & 141.02 \\
\hline \multirow{4}{*}{$\begin{array}{c}\text { M-44 } \\
\text { Donors }=4 \\
\text { Acceptors }=3\end{array}$} & C7-H9...O1 & 2.475 & 3.455 & 170.76 \\
\hline & C9-H10...O3 & 2.509 & 3.487 & 165.83 \\
\hline & C15-H17...O1 & 2.659 & 3.643 & 172.08 \\
\hline & $\mathrm{C} 21-\mathrm{H} 21 \ldots \mathrm{Cl}$ & 2.903 & 3.649 & 132.88 \\
\hline \multirow{4}{*}{$\begin{array}{c}\mathrm{M}-45 \\
\text { Donors }=4 \\
\text { Acceptors }=3\end{array}$} & $\mathrm{C} 4-\mathrm{H} 4 \ldots \mathrm{O} 3$ & 2.615 & 3.354 & 130.72 \\
\hline & C8-H8...O3 & 2.537 & 3.427 & 148.11 \\
\hline & C17-H17...O4 & 2.549 & 3.457 & 151.11 \\
\hline & $\mathrm{C} 21-\mathrm{H} 21 \ldots \mathrm{O} 1$ & 2.460 & 3.161 & 128.27 \\
\hline
\end{tabular}

The atom $\mathrm{C}$ acts as the most predominant hydrogen donor with frequency of occurrence at $68.8 \%$ and the $\mathrm{O}$ atom acts as hydrogen acceptor with frequency of occurrence at $98.9 \%$. The range for $\mathrm{d}(\mathrm{H} . . . \mathrm{A}), \mathrm{D}(\mathrm{X} \ldots \mathrm{A})$ and angular range $\mathrm{\Theta}(\mathrm{X}-\mathrm{H} . . \mathrm{A})$ for $\mathrm{C}-\mathrm{H} . . \mathrm{O}$ and $\mathrm{O}-\mathrm{H} \ldots \mathrm{O}$ intramolecular hydrogen bonds is presented in Table 6. In the case of intermolecular interactions, it has also been observed that that the $\mathrm{C}$ atom acts as the most predominant hydrogen donor with frequency of occurrence $68.8 \%$ and the $\mathrm{O}$ atom acts as hydrogen acceptor with frequency of occurrence $98.9 \%$. Most of the intermolecular C-H...O hydrogen 
bonds are observed in molecules having a keto group. The overall range $\mathrm{d}(\mathrm{H}$...A) lies between 1.655 and $2.92 \AA$, the $\mathrm{D}(\mathrm{X} . . . \mathrm{A})$ range is between 2.26 and $3.868 \AA$ and the angular range $\Theta(X-H . . . A)$ falls between 111.09 and $179^{\circ}$. The range for $d(H \ldots A), D(X . . A)$ and angular range $\Theta(\mathrm{X}-\mathrm{H} . . . \mathrm{A})$ for $\mathrm{C}-\mathrm{H} . . . \mathrm{O}, \mathrm{O}-\mathrm{H} . . . \mathrm{O}$ and $\mathrm{C}-\mathrm{H} . . . \mathrm{Br}$ intermolecular hydrogen bonds are presented in Table 6 .

Table 6. Range for $\mathrm{d}(\mathrm{H} . . \mathrm{A}), \mathrm{D}(\mathrm{X} . . \mathrm{A})$ and $\mathrm{\Theta}(\mathrm{X}-\mathrm{H} . . . \mathrm{A})$ for $\mathrm{C}-\mathrm{H} . . \mathrm{O}, \mathrm{O}-\mathrm{H} . . . \mathrm{O}$ and $\mathrm{C}-\mathrm{H} . . . \mathrm{Br}$ intra- and intermolecular hydrogen bonds

\begin{tabular}{llll}
\hline Type of bond & $\begin{array}{l}\mathrm{D}(\mathrm{H} . . \mathrm{A}) \\
\operatorname{range}(\AA)\end{array}$ & $\begin{array}{l}\mathrm{D}(\mathrm{X} \ldots \mathrm{A}) \\
\operatorname{range}(\AA)\end{array}$ & $\begin{array}{l}\mathrm{\Theta}(\mathrm{X}-\mathrm{H} \ldots \mathrm{A}) \\
\operatorname{range}\left({ }^{\circ}\right)\end{array}$ \\
\hline $\begin{array}{l}\text { Intramolecular } \\
\text { (a) } \mathrm{O}-\mathrm{H} \ldots \mathrm{O}\end{array}$ & $1.94-2.13$ & $2.71-2.86$ & $156-169$ \\
$\begin{array}{l}\text { Intermolecular } \\
\text { (a) } \mathrm{C}-\mathrm{H} \ldots \mathrm{O}\end{array}$ & $2.137-2.719$ & $2.920-3.688$ & $111.09-177.96$ \\
(b) $\mathrm{O}-\mathrm{H} \ldots \mathrm{O}$ & $1.655-2.635$ & $2.26-3.318$ & $130.49-179$ \\
(c) $\mathrm{C}-\mathrm{H} . . . \mathrm{Br}$ & $2.87-2.92$ & $3.788-3.868$ & $156-166$ \\
\hline
\end{tabular}

On the basis of interaction data, it may be concluded that $\mathrm{C}-\mathrm{H}$...O hydrogen bonding is predominant (frequency of occurrence $66.1 \%$ ) and it agrees well with the conclusions of Steiner \& Saenger (1992a) ${ }^{48}$. The C-H...O hydrogen bond is observed mostly in molecules having a keto group as substituent and the $\mathrm{O}-\mathrm{H}$...O hydrogen bond is found in molecules having the $\mathrm{OH}$ group as substituent.

\section{Graphical presentation of interactions}

The key structural feature distinguishing the hydrogen bond from the other non-covalent interactions is its preference for linearity ${ }^{49}$. A better way to analyse preferences is to draw d$\Theta$ and $D-\Theta$ scatter plots. The plots include all contacts found in molecules (1-45) with $d<$ $2.9 \AA$ and $\mathrm{D}<3.8 \AA$ at any occurring angle. The graphical projections of $\mathrm{d}-\mathrm{\Theta}$ [d(H...A) against $\Theta(\mathrm{X}-\mathrm{H} . . . \mathrm{A})]$ and $\mathrm{D}-\mathrm{\Theta}[\mathrm{D}(\mathrm{X} . . \mathrm{A})$ against $\Theta(\mathrm{X}-\mathrm{H} . . . \mathrm{A})]$ scatter plots have been made for intermolecular interactions which are shown in Figure $4(a, b)$. The following observations have been made:

(i) The density of spots for $\mathrm{d}(\mathrm{H} \ldots \mathrm{A})[=2.42-2.72 \AA]$ and $\mathrm{D}(\mathrm{X} \ldots \mathrm{A})[=3.3-3.6 \AA]$ is predominant in the theta $[\Theta(X-H . . . A)]$ range $\sim 120-179^{\circ}$ in the case of $\mathrm{C}-\mathrm{H} . . . \mathrm{O}$ hydrogen bonds.

(ii) The density of spots for $\mathrm{O}-\mathrm{H} . . \mathrm{O}$ intermolecular hydrogen bonds is quite high in a given range of values for $\mathrm{d}(\mathrm{H} . . . \mathrm{A})=1.90-2.15 \AA$ and $\mathrm{D}(\mathrm{X} . . . \mathrm{A})=2.32-2.90 \AA$ and $\Theta(\mathrm{X}-$ $\mathrm{H} . . . \mathrm{A})=150-179^{\circ}$.

(iii) The relative frequency of occurrence of various types of $\mathrm{C}-\mathrm{H} \ldots \mathrm{O}, \mathrm{O}-\mathrm{H} \ldots \mathrm{O}, \mathrm{C}-\mathrm{H} \ldots \mathrm{Br}$ and $\mathrm{C}-\mathrm{H} . . . \mathrm{Cl}$, and $\mathrm{C}-\mathrm{H} . . . \mathrm{F}$ intermolecular hydrogen bonds is $66.6,31.18,1.61,0.53$ and $0.53 \%$, respectively and it is shown in Figure 5.

Densely populated clusters of data points at short distances and fairly linear angles have been found and each point in these clusters represents a hydrogen bond. Plots analogous to these figures exist in the literature for other kinds of hydrogen bonds, such as O-H...O, CH...O, etc ${ }^{50}$. Similar features (preference for linearity) have been depicted by these plots which indicate that the angular characteristics of all kinds of hydrogen bonds are related. On comparison of the frequency of contacts from $\mathrm{H}(\mathrm{C})$ to $\mathrm{O}, \mathrm{Cl}, \mathrm{Br}$ and $\mathrm{F}$, it has been concluded that $\mathrm{H}(\mathrm{C})$ atoms have a statistical preference for contacts to ' $\mathrm{O}$ ' rather than ' $\mathrm{Br}$ ', ' $\mathrm{F}$ 'or ' $\mathrm{Cl}$ ' atoms. Thus, with oxygen as an acceptor, the frequency of occurrence of $\mathrm{C}-\mathrm{H}$...O hydrogen 
bond becomes very high ( $97.84 \%$ in the present case) In all the molecules (1-45), the C atoms act as donors but not as acceptors in all the bonds. Most of the C-H...O contacts have distance $\mathrm{d}(\mathrm{H}$...O) less than $2.7 \AA$ and based on the criterion that the van der Waals distance should be $<2.7 \AA$, it was regarded as a certain indication of hydrogen bonding.
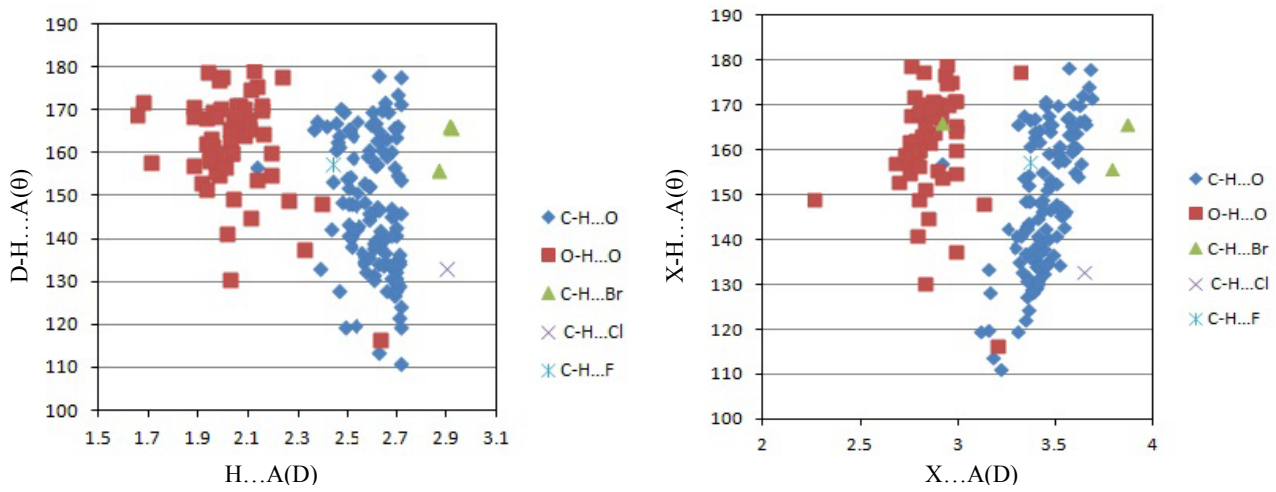

Figure 4. (a) d- $\theta$ scatter plot for intermolecular C-H... O, O-H... O, C-H...Br, C-H...CI and $\mathrm{C}-\mathrm{H}$...F hydrogen bonds (b) D- $\theta$ scatter plot for intermolecular C-H...O, O-H...O, C$\mathrm{H}$...Br, C-H...CI and C-H...F

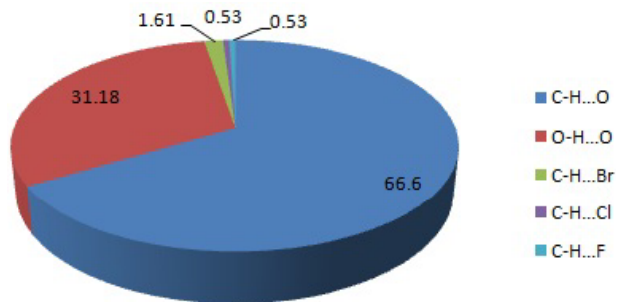

Figure 5. Relative frequency of occurrence (in \%) for various types of intermolecular hydrogen bonding

\section{Conclusion}

On comparison of some geometrical and structural features of the series of androstane derivatives, it is found that substituents are located mostly at $\mathrm{C} 3, \mathrm{C} 4$ and $\mathrm{C} 6$ position of the steroid nucleus. Hydrogen bonding interactions are present in these molecules and the substituents (at the $\mathrm{C} 3, \mathrm{C} 4$ and $\mathrm{C} 6$ position) which are involved in these interactions may be responsible for the lengthening and shortening of bond distances $\mathrm{C} 2-\mathrm{C} 3, \mathrm{C} 3-\mathrm{C} 4, \mathrm{C} 4-\mathrm{C} 5, \mathrm{C} 5-$ $\mathrm{C} 6$ and $\mathrm{C} 6-\mathrm{C} 7$. Hydrogen bonding may also be responsible for the deviation of $\mathrm{C} 2-\mathrm{C} 3-\mathrm{C} 4, \mathrm{C} 3-$ $\mathrm{C} 4-\mathrm{C} 5$ and $\mathrm{C} 5-\mathrm{C} 6-\mathrm{C} 7$ bond angles from its normal value. The bending in this bond angle typically amounts to only few degrees, which resembles the results shown by Desiraju \& Steiner ${ }^{51}$. Stress has been laid to study the hybridization (single/double bond) and ring fusions for the conformation of individual ring systems and stability of androstane molecules.

On comparing the hydrogen bond interactions, it is also concluded that the C-H...O hydrogen bonding is quite predominant in androstane class of steroids and the frequent contacts from $\mathrm{H}(\mathrm{C})$ atoms have a statistical preference to ' $\mathrm{O}$ ' as donor. The design of new molecules/supramolecules with desired properties is the future intention of chemists/crystallographers which requires the understanding of intermolecular interactions in crystal packing. Thus, understanding of intermolecular interactions becomes important. 


\section{Acknowledgement}

Rajni Kant is thankful to the Indian council of Medical Research, New Delhi for research funding under project grant no: BIC/12(14)2012.

\section{References}

1. Makin H L J, Biochemistry of Steroid Hormones, Oxford: Blackwell Scientific Publications, 1975a, 4.

2. Chand B, Ph.D. Thesis, Department of Physics \& Electronics, University of Jammu, Jammu Tawi, India, 2008.

3. Briggs $\mathrm{M}$ J and Brothern J, Steroid Biochemistry and Pharmacology, New York: Academic Press London, 1970, 121.

4. Gower D B and Bicknell D C, Acta Endocr., 1972, 70(3), 567-581.

5. Makin H L J, Biochemistry of Steroid Hormones, Oxford: Blackwell Scientific Publications, 1975b, 77.

6. Boeh H M, Handa S, Pattenden G, Roberts L, Blake A J and Li W S, J Chem Soc., Perkin Trans 1, 2000, 3522-3538; DOI:10.1039/B002999H

7. Freixa Z, Pereira, M M, Bayon J C, Silva A M S, Salvador J A R, Beja A M, Paixao J A and Ramos M, Tetrahedron Asymm., 2001 ,12(7), 1083-1087; DOI:10.1016/S09574166(01)00191-4

8. Armas H N, Peeters O M, Blaton N M, Ranter C J D, Garcia J A R, Moreno M R and Ginarte Y M A, Acta Crystallogr., Sect E: Struct Rep Online, 2001, 57(2), o166o167; DOI:10.1107/S1600536801001490

9. Chapdelaine D, Belzile J and Deslongchamps P, J Org Chem., 2002, 67(16), 56695672; DOI:10.1021/jo025612b

10. Andrade L C R, Paixao J A, Almeida M J M, Roleira F M F, Melo M L S, Neves A S C and Tavares da Silva E J, Acta Crystallogr., Sect E: Struct Rep Online, 2003, 59(1), o21-o23; DOI:10.1107/S1600536802022055

11. Guay B and Deslongchamps P, J Org Chem., 2003, 68(16), 6140-6148; DOI:10.1021/jo034280n

12. Paixao J I F, Salvador J A R, Paixao J A, Beja A M, Ramos S M and Gonsalves A M d'A, Acta Crystallogr., Sect C: Cryst Struct Commun., 2004 ,60, o630-o632;

DOI:10.1107/S0108270104011989

13. Uyanik C, Hanson J R, Nisius L and Hitchcock P B, J Chem Res., 2004, 471;

DOI: $10.5517 / \mathrm{cc} 7 \mathrm{kwsf}$

14. Andrade L C R, Paixao J A, de Almeida M J M, Tavares da Silva EJ, Roleira F M F, Acta Crystallogr., Sect E: Struct Rep Online, 2005, 61(4), o1144-o1146;

DOI: $10.1107 /$ S1600536805008895

15. Choudhary M I, Sultan S, Jalil S, Anjum S, Rahman A A., Hoong K F and Rahman A, Chem Biodiversity, 2005 ,2(3), 392; DOI:10.1002/cbdv.200590019

16. Ngatcha BT, Luu-T V, Labrie F, Poirier D, J Med Chem. , 2005, 48(16), 5257-5268; DOI:10.1021/jm058179h

17. Arteaga M A I, Rodriguez, F L L, Stivalet J M M and Alamo M F, Tetrahedron Lett., 2005, 46(16), 2771-2774; DOI:10.1016/j.tetlet.2005.02.149

18. Andrade LC R, Paixao J A, Almeida M J M, Roleira F M F, Silva E J T, Acta Crystallogr Sect C: Cryst Struct Commun., 2005 ,61,o131.

19. Andrade LC R, Paixao JA, de Almeida M J M, Fernandes Roleira F M and Silva E J T, Acta Crystallogr Sect C: Cryst Struct Commun., 2005, 61, o131-o133; DOI:10.1107/S0108270104034250 
20. Uyanik C, Malay A, Ayna A S, Hanson J R and Hitchcock P B, Steroids, 2005, 70(2), 71-75.

21. Uyanik C, Malay A, Ayna A S, Hanson J R and Hitchcock P B, Private Commun., 2005; DOI:10.5517/cc8xlmc

22. Hulme A T, Lancaster R W and Cannon H F, CrystEngComm , 2006, 8, 309-312; DOI:10.1039/B602909D

23. Kikolski, E M, Thompson H W and Lalancette R A, Acta Crystallogr., Sect C: Cryst Struct Commun. , 2006, 62, o397-o398; DOI:10.1107/S0108270106017677

24. Zhou W, Hu W X and Xia C N, Acta Crystallogr., Sect E: Struct Rep Online , 2007, 63(2), o615-o616; DOI:10.1107/S1600536806056145

25. Pinto R M A, Silva M R, Beja A M, Salvador J A R and Paixao J A, Acta Crystallogr Sect E:Struct Rep Online, 2007, 63(7), o3321; DOI:10.1107/S1600536807029893

26. Xia CN, Hu W X, Zhou W and Li B W, Acta Crystallogr., Sect E: Struct Rep Online, 2007, 63(3), o1249-o1250; DOI:10.1107/S1600536807005740

27. Xia C N, Li B W, Hu WX and Zhou W, Acta Crystallogr., Sect E: Struct Rep Online, 2007, 63(7), o3107; DOI:10.1107/S1600536807026803

28. Sheikh S E, Greffen A M, Lex J, Neudorfl J M and Schmalz H G, Synlett, 2007, 1881-1884; DOI:10.1055/s-2007-984521

29. Takata N, Shiraki K, Takano R, Hayashi Y and Terada K, Cryst Growth Des., 2008, 8(8), 3032-3037; DOI:10.1021/cg800156k

30. D'Accolti L, Fusco C, Lampignano G, Capitelli F and Curci R, Tetrahedron Lett., 2008, 49(39), 5614-5617; DOI:10.1016/j.tetlet.2008.07.042

31. Chambers R D, Nakano T, Parsons M, Sandford G, Batsanov A S and Howard J A K, J Fluorine Chem., 2008, 129(9), 811-816; DOI:10.1016/j.jfluchem.2008.04.010

32. Ke X, Hu H, Zhang K, Xu W, Zhu Q, Wu L and Hu X, Chem Commun., 2009, $1037-$ 1039; DOI:10.1039/B817910G

33. Yan X, Xu S, Wang J, Chen Y and Xia P, Acta Crystallogr., Sect E: Struct Rep Online, 2009, 65, o587; DOI:10.1107/S1600536809005741

34. Zhang S J, Xu F and Hu W X, J Chem Cryst., 2010, 40(11), 997-1001; DOI:10.1007/s10870-010-9782-y

35. Uyanik C and Koca O, J Chem Res., 2010, 34, 525-527.

36. Uyanik C, Malay A, Sonmez H B, Queudrue L and Hanson J R, Collect Czech Chem Commun., 2010, 75(4), 463-470.

37. Shi R, Zhang C S, Wei K, Acta Crystallogr., Sect E: Struct Rep Online, 2010, 66(4), o750; DOI:10.1107/S1600536810007555

38. Andrade L C R, de Almeida M J B M, Paixao J A, Carvalho J F S and Melo M L S, Acta Crystallogr., Sect E:Struct Rep Online, 2011, 67(5), o1056-o1057; DOI:10.1107/S1600536811011706

39. Andrade L C R, d.Almeida M J B M, Paixao J A, Carvalho J F S and Melo M L S, Acta Crystallogr., Sect E: Struct Rep Online, 2011, 67(7), o1643-o1644;

DOI:10.1107/S1600536811021349

40. Ramachary D B, Sakthidevi R and Reddy P S, RSC Adv., 2013, 3, 13497-13506; DOI:10.1039/C3RA41519H

41. Yamashita S, Naruko A, Yamada T, Hayashi Y and Hirama M, Chem Lett., 2013, 42, 220-221; DOI:10.1246/cl.2013.220

42. (a) Allen F H, Kennard O, Watson D G, Bramer L, Orpen A G and Taylor R, J Chem Soc Perkin Trans., 2, 1987, S1-S19; DOI:10.1039/P298700000S1; (b) Sutton L E, 
Tables of Interatomic Distances and Configurations in Molecules and Ions, Spec. Publ. No. 18. London: The Chemical Society, 1965.

43. Duax W L and Norton D A, Atlas of Steroid Structure, Vol. 1, New York: Plenum Press, 1975, 18.

44. (a) Geronikaki A, Druzhilovsky D, Zakharov A and Poroikov V, SAR \& QSAR Environ Res., 2008, 19, 27-38; DOI:10.1080/10629360701843649 (b) Filz O A and Poroikov V V, Russian Chem Rev., 2012, 81(2), 158-174; DOI:10.1070/RC2012v081n02ABEH004222

45. Pauling L, The Nature of the Chemical Bond, Cornell University Press, Ithaca, NY, 1939.

46. Jeffrey G A and Saenger W, Hydrogen Bonding in Biological Structures, SpringerVerlag, Berlin, 1991.

47. Calhorda M J, Chem Commun., 2000, 801-809; DOI:10.1039/A900221I

48. Steiner $\mathrm{T}$ and Saenger W, Acta Cryst B, 1992a, 48(6), 819-827; DOI:10.1107/S0108768192004336

49. Steiner T, Angew Chem Int Ed Engl., 2002, 41(1), 48-76; DOI:10.1002/15213773(20020104)41:1<48::AID-ANIE48>3.0.CO;2-U

50. Steiner $\mathrm{T}$ and Saenger W, J Am Chem Soc., 1992b, 114(26), 10146-10154; DOI:10.1021/ja00052a009

51. Desiraju G R and Steiner T, The Weak Hydrogen Bond in Structural Chemistry and Biology. IUCr/Oxford University Press, 1999. 